\title{
An enzymatically activated fluorescence probe for targeted tumor imaging
}

\author{
Mako Kamiya ${ }^{\dagger} \ddagger$, Hisataka Kobayashi $§,{ }^{*}$, Yukihiro Hama§, Yoshinori Koyama§, Marcelino \\ Bernardo§, Tetsuo Nagano $\uparrow, \ddagger$, Peter L. Choyke§, and Yasuteru Urano $\dagger, \uparrow,{ }^{*}$ \\ $\dagger$ Graduate School of Pharmaceutical Sciences, The University of Tokyo, 7-3-1 Hongo, Bunkyo-ku, Tokyo \\ 113-0033, Japan \\ $\$ C R E S T$, Japan Science and Technology Agency, Kawaguchi, Saitama, Japan \\ §Molecular Imaging Program, Center for Cancer Research, National Cancer Institute, National Institutes of \\ Health, Bldg. 10, Rm. 1B40, 10 Center Dr., Bethesda, MD 20892-1088
}

TPRESTO, Japan Science and Technology Agency, Kawaguchi, Saitama, Japan

\section{Abstract}

$\beta$-Galactosidase is a widely used reporter enzyme, but although several substrates are available for in vitro detection, its application for in vivo optical imaging remains a challenge. To obtain a probe suitable for in vivo use, we modified our previously developed activatable fluorescence probe, TG$\beta \mathrm{Gal}$ (J. Am. Chem. Soc., 2005, 127, 4888-4894), on the basis of photochemical and photophysical experiments. The new probe, AM-TG- $\mathbf{\beta G a l}$, provides a dramatic fluorescence enhancement upon reaction with $\beta$-galactosidase, and further hydrolysis of the ester moiety by ubiquitous intracellular esterases affords a hydrophilic product that is well retained within the cells without loss of fluorescence. We used a mouse tumor model to assess the practical utility of AM-TG- $\boldsymbol{\beta G a l}$, after confirming that tumors in the model could be labeled with avidin- $\beta$-galactosidase conjugate. This conjugate was administered to the mice in vivo, followed by AM-TG-BGal, and subsequent $e x$ vivo fluorescence imaging clearly visualized intraperitoneal tumors as small as $200 \mu \mathrm{m}$. This strategy has potential clinical application, for example in video-assisted laparoscopic tumor resection.

\section{Introduction}

Marker enzymes are widely used to identify cell types or specific haptens, to examine transcription regulation, or to evaluate the efficiency of transfection experiments. Escherichia coli $\beta$-galactosidase is well characterized and extensively used as a marker enzyme in enzymelinked immunosorbent assays (ELISA),${ }^{1-3}$ in situ hybridizations, ${ }^{4-6}$ classification of mycobacteria, ${ }^{7}$ and gene expression studies. ${ }^{8-11}$ This enzyme is especially useful for studying gene expression because of its stability, high turnover rate, and ease of conjugation and detection, as well as the absence of endogenous $\beta$-galactosidase activity in eukaryotic cells. A range of substrates has been developed including colorimetric, ${ }^{12,13}$ fluororescence, ${ }^{14-19}$ chemluminescence, ${ }^{20,21}$ and paramagnetic probes, ${ }^{22}$ though they have mostly been used in in vitro systems, with only a few successful applications in vivo. ${ }^{23-25}$

In our previous work, we focused on simple, rapid, and sensitive detection of $\beta$-galactosidase activity, and developed a highly sensitive fluorescence probe for $\beta$-galactosidase, TG- $\beta \mathrm{Gal}$ (Scheme 1a). ${ }^{26}$ This probe was rationally designed to show a dramatic fluorescence activation

\footnotetext{
* To whom correspondence should be addressed. E-mail: kobayash@mail.nih.gov or urano@mol.f.u-tokyo.ac.jp.
} 
(up to 440-fold) upon reaction with $\beta$-galactosidase, and was successfully used to visualize $\beta$ galactosidase activity in living cells. We considered that such probes might be suitable to visualize tumors in vivo. For example, in the clinical field, video-assisted laparoscopic surgery is becoming one of the standard methods for resecting metastases, ${ }^{27}$ and it already relies on optical cameras that could easily be adapted to employ fluorescence imaging. 28 Probes such as TG- $\beta$ Gal have appropriate characteristics (high molar extinction coefficient and high fluorescence quantum yield in aqueous media after reaction with the target enzymes) for visualization of surface tumors such as intraperitoneal tumors, for which brightness of the fluorophores is more important than long-wavelength excitability, as the light does not need to penetrate the skin and tissues. Our aim in the present work was to design a TG- $\beta$ Gal-based probe that would be suitable for in vivo tumor imaging and to test its suitability for this purpose in an animal tumor model. TG- $\beta$ Gal itself was unsuitable, as its hydrophobic fluorescent hydrolysis product is easily washed out from cells (Figure 1a). We therefore designed and

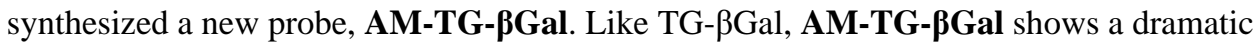
fluorescence enhancement upon hydrolysis with $\beta$-galactosidase. Further, the ester moiety of its hydrolysis product, AM-TG, is cleaved by ubiquitous intracellular esterases, generating a hydrophilic product that is well retained within the cells without loss of fluorescence. To examine whether AM-TG-BGal would indeed be suitable for in vivo tumor imaging, we used the following two-step strategy in a mouse tumor model. First, avidin- $\beta$-galactosidase conjugate was administered to the mice to target the enzyme to tumors, then AM-TG-קGal was administered. Subsequent ex vivo fluorescence imaging clearly visualized intraperitoneal tumors as small as $200 \mu \mathrm{m}$. Our findings demonstrate the feasibility of this approach to tumor imaging, which we believe has potential clinical applicability, for example in video-assisted laparoscopic tumor resection.

\section{Results and Discussion}

\section{Design and synthesis of new probes with improved cellular retention}

We aimed to modify TG- $\beta$ Gal to obtain sufficient intracellular retention in the living cells by adopting the strategy of introducing an acetoxymethyl (AM) ester group. ${ }^{29,30} \mathrm{We}$ anticipated that the AM-derivatized $\beta$-galactosidase probe would be hydrolyzed both by $\beta$-galactosidase to show large fluorescence activation, and by ubiquitous intracellular esterases to yield the hydrophilic fluorophore with a free carboxylate group, which would not readily leak from the cells.

From the synthetic point of view, we first thought it would be simple to introduce a methoxycarbonyl methoxy group instead of the methoxy group of TG- $\beta$ Gal. According to Scheme 2, we synthesized $\underline{\mathbf{1}}^{\text {Me }} \boldsymbol{\beta}$ Gal. Although $\underline{\mathbf{1}}^{\mathbf{M e}}$ (the hydrolysis product of $\underline{\mathbf{1}}^{\mathrm{Me}} \boldsymbol{\beta} \mathbf{\beta G a l}$ ) is highly fluorescent $\left(\Phi_{\mathrm{fl}}=0.85\right), \underline{\mathbf{1}}^{\mathrm{Me}} \boldsymbol{- \beta G a l}$ had a relatively high background fluorescence $\left(\Phi_{\mathrm{fl}}=0.069\right)$, so the fluorescence enhancement after activation was relatively modest (46-fold) (Table 1, Scheme 1b).

In order to understand this result, we have to consider the mechanism underlying the fluorescence off/on switching of TG- $\beta \mathrm{Gal}$, i.e., intramolecular photoinduced electron transfer $(\mathrm{PeT})$, which is a non-radiative pathway from the excited state of the fluorophore. As we demonstrated in our previous paper, fluorescein derivatives, including TokyoGreens, can be considered to consist of two functional components from the viewpoint of fluorescence, namely a benzene moiety which is the electron donor and a xanthene moiety which is the fluorophore (Scheme 1a). ${ }^{31,32}$ Moreover, the oxidation potential of the benzene moiety can greatly influence the efficiency of PeT, and $m$-methoxytoluene, the benzene moiety of TG- $\beta \mathrm{Gal}$, has the most suitable oxidation potential as an electron donor (1.66 V vs SCE, Table 2 ) in order to convert the change in reduction potential of the xanthene moiety induced by $\beta$-galactosidaseassisted hydrolysis to the maximal change in fluorescence intensity. ${ }^{26}$ Therefore, we measured 
the oxidation potential of $m$-methoxycarbonylmethoxytoluene, the benzene moiety of $\underline{1}^{\mathrm{Me}}$

$\boldsymbol{\beta G a l}\left(\operatorname{Bn}\left(\underline{1}^{\mathbf{M e}}\right)\right)$, and found that the oxidation potential had been altered to a higher value (1.77 $\mathrm{V}$ vs SCE, Table 2) by the introduction of the electron-withdrawing methoxycarbonyl group with a short methylene linker, and this accounted for the increase of the background fluorescence of $\underline{1}^{\mathrm{Me}} \boldsymbol{- \beta G a l}$. The calculated energy level of the highest occupied molecular orbital (HOMO), which is known to be linearly correlated with measured oxidation potential, supported this view (-0.02141 hartree for $m$-methoxytoluene and - 0.02207 hartree for Bn $\left.\left(\underline{1}^{\text {Me }}\right)\right)($ Table 2).

Thus, we employed a strategy to lower the oxidation potential of $\mathbf{B n}\left(\underline{1}^{\mathbf{M e}}\right)$ to a similar value to that of $m$-methoxytoluene (1.66 V vs SCE) by introducing an electron-donating group. The oxidation potential of $m$-methoxycarbonylmethoxyanisole $\left(\mathbf{B n}\left(\underline{\mathbf{2}}^{\mathbf{M e}}\right)\right)$, in which the methyl group of $\mathbf{B n}\left(\underline{\mathbf{1}}^{\mathbf{M e}}\right)$ is replaced with a methoxy group, proved to be sufficiently small to suppress the background fluorescence ( $1.57 \mathrm{~V}$ vs SCE, Table 2 ) via the PeT pathway. Thus, we designed and synthesized $\underline{\mathbf{2}}^{\mathbf{M e}}$ - $\mathbf{\beta G a l}$ according to Scheme 3 . As we expected, $\underline{\mathbf{2}}^{\mathbf{M e}}-\boldsymbol{\beta} \mathbf{G a l}$ showed low background fluorescence $\left(\Phi_{\mathrm{fl}}=0.004\right)$, whereas $\underline{\mathbf{2}}^{\mathrm{Me}}$ (the hydrolysis product of $\underline{\mathbf{2}}^{\mathbf{M e}} \boldsymbol{\beta} \mathbf{\beta G a l}$ ) showed strong fluorescence $\left(\Phi_{\mathrm{fl}}=0.67\right)$ (Table 1$)$. Thus, the fluorescence enhancement is 410 fold. Unfortunately, however, the fluorescence intensity of $\underline{2}^{\mathbf{M e}}$ was altered by esterase activity, because hydrolysis of the ester group lowered the oxidation potential too much, which led to quenching of the fluorescence output of $\underline{\mathbf{2}}\left(\Phi_{\mathrm{fl}}=0.32\right)$, the final fluorescent species generated from $\underline{2}^{\mathrm{Me}} \boldsymbol{\beta} \mathbf{\beta G a l}$ (Scheme $1 \mathrm{~b}$, Table 1, Figure 2). For the reliable fluorescence detection of $\beta$ galactosidase activity, the fluorescence should be unaffected by cleavage of the ester.

The solution we adopted was to reduce the electron-withdrawing effect of the methoxycarbonyl group of $\mathbf{B n}\left(\underline{1}^{\mathrm{Me}}\right)$ by lengthening the methylene chain between the methoxycarbonyl group and the benzene moiety. We calculated the HOMO energy levels of the benzene moiety with various lengths of methylene chain at the B3LYP/6-31G level, and predicted that a HOMO level similar to that of $m$-methoxytoluene could be achieved by inserting three or four methylene units between the methoxycarbonyl group and the benzene moiety (Table 2). Oxidation potentials of $m$-methoxycarbonylbutyloxytoluene $\left(\mathbf{B n}\left(\underline{3}^{\mathrm{Me}}\right)\right)$ measured by cyclic voltammetry were consistent with this expectation (1.62 V vs SCE, Table 2). According to Scheme 4, we synthesized $\underline{\mathbf{3}}^{\mathbf{M e}} \boldsymbol{\beta} \boldsymbol{\beta} \mathbf{G a l}$ with four methylene units. The background fluorescence of $\underline{\mathbf{3}}^{\mathrm{Me}} \boldsymbol{\beta} \mathbf{\beta G a l}$ was successfully suppressed $\left(\Phi_{\mathrm{fl}}=0.009\right)$, while the hydrolysis product of $\underline{\mathbf{3}}^{\mathrm{Me}}$ $\boldsymbol{\beta G a l}\left(\underline{\mathbf{3}}^{\text {Me }}\right)$ emits sufficiently strong fluorescence $\left(\Phi_{\mathrm{fl}}=0.85\right)($ Scheme $1 \mathrm{~b}$, Table 1$)$. The fluorescence enhancement ratio that can be obtained with $\underline{\mathbf{3}}^{\mathrm{Me}} \mathbf{\beta} \mathbf{\beta G a l}$ is approximately 360 -fold. Moreover, its fluorescence was independent of the esterase activity ( $\Phi_{\mathrm{fl}}$ of $\underline{\mathbf{3}}$ was 0.85 , Figure 2). Therefore, we derivatized $\underline{\mathbf{3}}^{\mathrm{Me}} \boldsymbol{\beta} \mathbf{\beta G a l}$ to the AM ester, which was designated AM-TG$\boldsymbol{\beta G a l}$ (Scheme 5). As expected, AM-TG- $\boldsymbol{\beta G a l}$ shows almost no fluorescence $\left(\Phi_{\mathrm{fl}}=0.005\right)$, but is converted by $\beta$-galactosidase to highly fluorescent AM-TG $\left(\Phi_{\mathrm{fl}}=0.86\right)$, affording a 470 fold fluorescent enhancement (Scheme 1c, Table 1, Figure 3). Thus, we finally succeeded in developing a highly sensitive fluorescence probe for $\beta$-galactosidase with an esterase-sensitive moiety that could be removed without loss of the strong fluorescence, by finely tuning the oxidation potential to retain the highly activatable character of TG- $\beta$ Gal.

\section{Relationship between oxidation potential and fluorescence quantum yield}

We plotted the fluorescence quantum yields of the anionic and neutral forms of $\underline{1}^{\mathrm{Me}}, \underline{\mathbf{2}}^{\mathrm{Me}}$, $\underline{\mathbf{3}}^{\mathrm{Me}}$ (the scaffold fluorophores of $\underline{\mathbf{1}}^{\mathrm{Me}} \boldsymbol{\beta} \mathbf{\beta G a l}, \underline{\mathbf{2}}^{\mathrm{Me}} \boldsymbol{\beta} \mathbf{\beta G a l}, \underline{\mathbf{3}}^{\mathrm{Me}} \boldsymbol{- \beta G a l}$ ) on a graph showing the relationship between the oxidation potential and fluorescence quantum yield $\left(\Phi_{\mathrm{fl}}\right)$ of previously reported TokyoGreen derivatives (Figure 4, Table 3). ${ }^{26}$ All the values including that of $\underline{\mathbf{1}}^{\mathbf{M e}}$, $\underline{\mathbf{2}}^{\mathbf{M e}}, \underline{\mathbf{3}}^{\mathbf{M e}}$ can be fitted with the Marcus equation. It can be seen that $\underline{\mathbf{3}}^{\mathrm{Me}}$ lies between the fluorescence off/on thresholds of the anionic and neutral forms, indicating that it is the most suitable scaffold fluorophore for developing a highly sensitive fluorescence probe with 
enhanced cellular retention. This result also confirms that the previously reported design strategy is valid for developing new probes with desirable features.

\section{Cellular retention}

We next examined whether or not the newly developed AM-TG- $\beta$ Gal is better retained in living cells as compared with TG- $\beta$ Gal. HEK293 cells expressing $\beta$-galactosidase were incubated with $10 \mu \mathrm{M}$ AM-TG-BGal, and fluorescence images were captured before and after washing of the cells (Figure 1b). As expected, washing caused little change of the fluorescence, in contrast with the case of TG- $\beta \mathrm{Gal}$. This difference can be explained in terms of superior retention of the ultimate hydrolysis product of AM-TG-BGal in the living cells.

\section{Targeting of $\beta$-galactosidase to tumor cells}

We next tried to apply AM-TG-ßGal to visualize intraperitoneal tumors in mice. For this purpose, we adopted a two-step procedure, employing a tumor-targeting avidin- $\beta$ galactosidase conjugate (avidin- $\beta$-galactosidase) to localize $\beta$-galactosidase to cancer cells in vivo, 33,34 followed by the administration of AM-TG-BGal. Avidin was chosen based on its high affinity for lectins on the surface of several human ovarian cancer cell lines, including SHIN3 cells. ${ }^{35-37}$ The tumor model in mice was prepared as reported. ${ }^{38}$ As a first step, we examined whether avidin- $\beta$-galactosidase could be targeted to SHIN3 cells in vivo by injecting it intraperitoneally into mice bearing peritoneal SHIN3 tumors. Twenty hours later, the organs were harvested and stained with X-Gal. After further incubation for 2 hours, a blue precipitate was observed only in the disseminated tumor, confirming that avidin- $\beta$-galactosidase can be efficiently targeted to SHIN3 cells in vivo without loss of the enzymatic activity (Figure 5).

\section{Fluorescence detection of tumors in vivo}

We next tried to visualize tumors pre-labelled with avidin- $\beta$-galactosidase by employing AM-

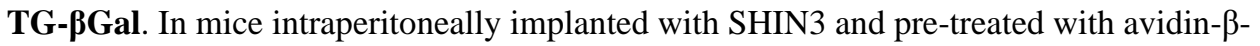
galactosidase (ip), intraperitoneal administration of AM-TG-BGal followed by incubation for 1 hour revealed strongly fluorescent spots in the peritoneal cavity (Figure 6a and $6 \mathrm{~b}$ ). Although the incubation time required for imaging is likely to vary depending on the size of the tumor, one-hour incubation produced clearer fluorescence signals than 30-minute incubation in our experiment. Small tumors on the mesenterium were clearly seen (Figure 6c), and fluorescence microscopy revealed spots as small as $200 \mu \mathrm{m}$ (Figure 6d). The fluorescence enhancement at microfoci over the surrounding tissues on the mesenterium is up to 33-fold (Supporting Figure S1). In contrast, almost no fluorescence activation could be observed in normal, tumor-free mouse treated with avidin- $\beta$-galactosidase and AM-TG- $\beta$ Gal (Supporting Figure S2). Mice given TG- $\beta$ Gal also showed a marked fluorescence increase in the peritoneal cavity, but this was unlikely to have been confined to tumors, owing to the leakage of the fluorescent product derived from TG- $\beta$ Gal (Figure 6e). Indeed, the fluorescence signal produced by AM-TG$\boldsymbol{\beta G a l}$ at the tumors was not decreased by washing, in contrast to the case with TG- $\beta \mathrm{Gal}$, suggesting that our strategy of using the hydrolyzable AM moiety did indeed improve cellular retention of the fluorescent product (Figure 7). Staining of tissue with X-Gal showed a similar distribution to that of the fluorescence signal produced by AM-TG-BGal, indicating that the fluorescence signal was co-localized with the $\beta$-galactosidase activity (Figure 8). As regards the specificity of the staining, it has previously been shown that at least $99 \%$ of the small spots in the peritoneal cavity in this tumor model are tumors (Supporting Figure S3). ${ }^{35}$ These results suggest that AM-TG- $\beta$ Gal had been hydrolyzed both by the SHIN3-targeted $\beta$-galactosidase, leading to fluorescence activation, and by intraplasmic esterase, resulting in good retention within cells. 


\section{Conclusion}

There is increasing interest in in vivo optical imaging of $\beta$-galactosidase in the biological and clinical fields, but with limited success so far. ${ }^{23-25}$ We have developed AM-TG-ßGal as a highly sensitive fluorescence probe for $\beta$-galactosidase that is suitable for targeted tumor imaging in vivo. It represents a development of our previously reported fluorescence probe for $\beta$-galactosidase, ${ }^{26}$ modified by introducing AM ester into TG- $\beta$ Gal through a precisely optimized linker while retaining the advantageous optical properties of TG- $\beta$ Gal. AM-TG-

$\boldsymbol{\beta G a l}$ exhibits a drastic fluorescence enhancement upon reaction with $\beta$-galactosidase, and is well retained intracellularly after hydrolysis by ubiquitous intracellular esterases without loss of fluorescence. Moreover, we devised a two-step strategy for highly activatable optical imaging of intraperitoneal tumor cells without the need for prior transfection of reporter enzymes. First, a conjugate of a tumor-targeting molecule and the enzyme, avidin- $\beta$ galacotosidase, is administered and binds via avidin to the tumor cell surface. Secondly, AMTG- $\boldsymbol{\beta G a l}$ is administered, and is hydrolyzed to AM-TG by $\beta$-galactosidase bound to the tumor cells. AM-TG exhibits both highly activated fluorescence and enhanced permeability, and is readily transferred into nearby tumor cells, where it is hydrolyzed to the free carboxylate by cytoplasmic esterases. This procedure provides a tumor-specific, long-lived, and highly activated fluorescence signal. Studies to examine the feasibility of using this approach in videoassisted laparoscopic surgery are in progress. The present results indicate that chemistry-based fine-tuning of chemical properties (both fluorescence and cell permeability) could be the key to the development of small-molecular "magic bullets" in the fields of biology and clinical medicine, and we believe that the range of potential applications of our new probe is enormous.

\section{Experimental Section}

All procedures were carried out in compliance with the Guide for the Care and Use of Laboratory Animal Resources (1996), National Research Council, and approved by the National Cancer Institute Animal Care and Use Committee. All experiments were carried out at $25^{\circ} \mathrm{C}$, unless otherwise specified.

\section{Materials and instruments}

Chemicals used for organic synthesis were of the best grade available, supplied by Tokyo Chemical Industries, Wako Pure Chemical or Aldrich Chemical Company, and were used without further purification. ${ }^{1} \mathrm{H}-\mathrm{NMR}$ spectra and ${ }^{13} \mathrm{C}-\mathrm{NMR}$ spectra were recorded on a JNMLA300 (JEOL) instrument at $300 \mathrm{MHz}$ and $75 \mathrm{MHz}$, and on a JNM-AL400 (JEOL) instrument at $400 \mathrm{MHz}$. Mass spectra (MS) were measured with a SX-102A (JEOL) for EI, a MS700 (JEOL) for FAB and a JMS-T100LC (JEOL) for ESI-TOF.

\section{UV/VIS and fluorescence analysis}

For the absorption or fluorescence measurement, compounds were dissolved in dimethyl sulfoxide (DMSO, fluorometric grade, Dojindo) to obtain $10 \mathrm{mM}$ stock solutions. These stock solutions were diluted with buffer as specified in the figure legends, to the desired concentration. For determination of the quac $\left(\Phi_{\mathrm{fl}}\right)$, fluorescein in $100 \mathrm{mM}$ aq. $\mathrm{NaOH}\left(\Phi_{\mathrm{fl}}=\right.$ 0.85 ) was used as a fluorescence standard. ${ }^{39} \beta$-Galactosidase and porcine liver esterase were purchased from Sigma-Aldrich Japan K.K. All absorption spectra were obtained with a 8453 UV/Vis spectrometer (Agilent) or with a UV-1600 UV/Vis spectrometer (Shimadzu). All fluorescence spectra were obtained with a LS-55 fluorescence spectrometer (Perkin-Elmer) or a F4500 fluorescence spectrometer (Hitachi). 


\section{Cyclic voltammetry}

Cyclic voltammetry was performed on a 600A electrochemical analyzer (ALS). A threeelectrode arrangement in a single cell was used for the measurements: a Pt wire as the auxiliary electrode, a glassy carbon electrode as the working electrode, and an $\mathrm{Ag} / \mathrm{Ag}^{+}$electrode as the reference electrode. The sample solutions contained $1.0 \mathrm{mM}$ sample and $100 \mathrm{mM}$ tetrabutylammonium perchlorate (TBAP) as a supporting electrolyte in acetonitrile, and argon was bubbled for $10 \mathrm{~min}$ before each measurement. Obtained potentials (vs. $\mathrm{Ag} / \mathrm{Ag}^{+}$) were converted to those vs. SCE by adding $0.248 \mathrm{~V}$.

\section{Photochemical calculation}

HOMO energy levels were calculated at the B3LYP/6-31G level with Gaussian 98W.

\section{Intracellular retention assay}

HEK293 cells expressing $\beta$-galactosidase were incubated with a $10 \mu \mathrm{M}$ solution of TG- $\beta \mathrm{Gal}$ or AM-TG-ßGal in physiological salt solution, $\mathrm{pH} 7.4$, containing $150 \mathrm{mM} \mathrm{NaCl}, 4 \mathrm{mM} \mathrm{KCl}$, $2 \mathrm{mM} \mathrm{CaCl}_{2}, 1 \mathrm{mM} \mathrm{MgCl}_{2}, 5 \mathrm{mM}$ HEPES, and $0.1 \%$ glucose (PSS), and $0.1 \% \mathrm{DMSO}$ as a cosolvent for 2 hours. Then, confocal fluorescence images and DIC images were captured before and after washing with PSS. The images were obtained with an Olympus fluoview system using an IX81 inverted microscope, an Ar ion laser, and a PlanApo 40x/1.40 objective lens (Olympus, Tokyo, Japan). The excitation wavelength was $488 \mathrm{~nm}$, and the emission wavelength was $510-550 \mathrm{~nm}$.

\section{Mouse preparation}

The intraperitoneal tumor model was prepared as previously reported. ${ }^{38}$ Briefly, $2 \times 10^{6}$ SHIN3 cancer cells suspended in PBS(-) were injected intraperitoneally into female nude mice (National Cancer Institute Animal Production Facility, Frederick, MD, USA). Experiments with these tumor-harboring mice were performed at 10-13 days after dissemination, when numerous small, intraperitoneally disseminated tumors had formed, especially around the stomach, the subphrenic region, at the hepatic and splenic hila, and on the mesentery.

\section{Biodistribution of avidin- $\beta$-galactosidase in vivo}

Avidin- $\beta$-galactosidase (100 $\mu \mathrm{g})$ in PBS(-) was injected intraperitoneally into tumor-bearing mice. Twenty hours later, the mice were sacrificed by exposure to $\mathrm{CO}_{2}$ gas. The main internal organs (tumor, mesentery, intestine, stomach, liver, kidney, spleen, lung, heart) were removed for routine $\mathrm{X}$-Gal staining.

\section{Fluorescence imaging of tumors in a mouse tumor model}

Avidin- $\beta$-galactosidase (100 $\mu \mathrm{g})$ in PBS(-) was injected intraperitoneally into a tumor-bearing mouse and, which was left for 16-23 hours. Then, a $3.3 \mu \mathrm{M}$ solution of AM-TG- $\beta$ Gal was injected. After 1 hour, the mouse was sacrificed under anesthesia, and the abdominal walls were removed. Fluorescence images in the peritoneal cavity were captured with a Maestro ${ }^{\mathrm{TM}}$ In-Vivo Imaging System (CRI Inc., Woburn, MA, USA). The excitation wavelength was $445-490 \mathrm{~nm}$. Spectral unmixing was performed to obtain the fluorescence unmixed images. Fluorescence images of tumor nodules on the mesentery were captured with a BX51 microscope (Olympus USA, Melville, NY) equipped with an UPLAPO10x objective lens (Olympus USA, Melville, NY).

\section{Synthesis of 2-Bromo-5-(tert-butyldimethylsilyloxy)toluene (1)}

A mixture of 4-bromo-3-methylphenol (2 g, $10.7 \mathrm{mmol})$, tert-butyldimethylsilyl chloride (TBDMS-Cl) $(4.8 \mathrm{~g}, 30 \mathrm{mmol})$, and imidazole $(3.6 \mathrm{~g}, 50 \mathrm{mmol})$ in dry DMF $(10 \mathrm{ml})$ was stirred 
at room temperature under argon for 3 hours. The solvent was concentrated under reduced pressure. The residue was diluted with water and extracted with $\mathrm{CH}_{2} \mathrm{Cl}_{2}$ three times. The combined organic solution was washed with water and saturated aq. $\mathrm{NaCl}$, dried over $\mathrm{Na}_{2} \mathrm{SO}_{4}$ and evaporated to give 1 as a colorless clear oil $(3.04 \mathrm{~g}, 95 \%) .{ }^{1} \mathrm{H} \mathrm{NMR}(300 \mathrm{MHz}$, $\left.\mathrm{CDCl}_{3}\right): \delta 7.33(\mathrm{~d}, 1 \mathrm{H}, J=8.6 \mathrm{~Hz}), 6.72(\mathrm{~d}, 1 \mathrm{H}, J=2.9 \mathrm{~Hz}), 6.53(\mathrm{dd}, 1 \mathrm{H}, J=8.6 \mathrm{~Hz}, 2.9 \mathrm{~Hz})$, $2.32(\mathrm{~s}, 3 \mathrm{H}), 0.97(\mathrm{~s}, 9 \mathrm{H}), 0.18(\mathrm{~s}, 6 \mathrm{H}) ;{ }^{13} \mathrm{C} \mathrm{NMR}\left(75 \mathrm{MHz}, \mathrm{CDCl}_{3}\right): \delta 154.88,138.79,132.76$, 122.59, 119.10, 116.16, 25.64, 22.98, 18.18, -4.48; MS (FAB): $m / z$ 301, $303(\mathrm{M}+1)^{+}$.

\section{Synthesis of 9-\{1-[4-(tert-Butyldimethylsilyloxy)-2-methylphenyl]\}-6-hydroxy-3H-xanthen-3- one (2)}

A solution of $1(1.28 \mathrm{~g}, 4.27 \mathrm{mmol})$ in distilled THF $(10 \mathrm{ml})$ was cooled down to $-78{ }^{\circ} \mathrm{C}$ (dry ice-acetone). $t$-Butyllithium in $n$-pentane solution $(4.5 \mathrm{ml}, 6.57 \mathrm{mmol}$ ) was added dropwise to the reaction mixture using a syringe. 3,6-Bis-( $t$-butyldimethylsilanyloxy)xanthen-9-one (1.07 $\mathrm{g}, 2.37 \mathrm{mmol})$ dissolved in distilled THF $(20 \mathrm{ml})$ was added dropwise to the mixture using a syringe. The mixture was stirred at $-78^{\circ} \mathrm{C}$ under argon for $30 \mathrm{~min}$, then $2 \mathrm{~N}$ aq. $\mathrm{HCl}$ was added, and the red precipitate was collected by filtration. The precipitate was chromatographed on silica gel with $\mathrm{CH}_{2} \mathrm{Cl}_{2}-\mathrm{MeOH}$ (100:3-100:5) as the eluent to give 2 as an orange powder (774.6 $\mathrm{mg}, 82 \%) .{ }^{1} \mathrm{H}$ NMR (300 MHz, $\left.\mathrm{CD}_{3} \mathrm{OD}\right): \delta 7.27$ (d, $\left.2 \mathrm{H}, J=9.2 \mathrm{~Hz}\right), 7.15(\mathrm{~d}, 1 \mathrm{H}, J=8.3 \mathrm{~Hz})$, 7.01-6.86 (m, 6H), $2.01(\mathrm{~s}, 3 \mathrm{H}), 1.06(\mathrm{~s}, 9 \mathrm{H}), 0.31$ (s, 6H); HRMS(ESI $\left.{ }^{-}\right)$: calcd for [M-H] ${ }^{-}$, 431.16786; found, 431.16636.

\section{Synthesis of 9-[1-(4-hydroxy-2-methylphenyl)]-6-hydroxy-3H-xanthen-3-one (3)}

To a solution of $2(2.62 \mathrm{~g}, 6.2 \mathrm{mmol})$ in distilled THF $(200 \mathrm{ml})$, a $1 \mathrm{M}$ solution of tetrabutylammonium fluoride in THF $(6.2 \mathrm{ml}, 6.2 \mathrm{mmol})$ was added. The mixture was stirred at room temperature under argon for 2 hours, then evaporated, and the residue was chromatographed on silica gel with $\mathrm{CH}_{2} \mathrm{Cl}_{2}-\mathrm{MeOH}(100: 5-100: 7)$ as the eluent to give 3 as an orange powder $(1.13 \mathrm{~g}, 58 \%) .{ }^{1} \mathrm{H}$ NMR $\left(300 \mathrm{MHz}, \mathrm{CD}_{3} \mathrm{OD}\right): \delta 7.06(\mathrm{~d}, 2 \mathrm{H}, J=9.7 \mathrm{~Hz})$, $6.94(\mathrm{~d}, 1 \mathrm{H}, J=8.2 \mathrm{~Hz}), 6.78$ (d, $1 \mathrm{H}, J=2.4 \mathrm{~Hz}), 6.74(\mathrm{dd}, 1 \mathrm{H}, J=8.2 \mathrm{~Hz}, 2.4 \mathrm{~Hz}), 6.63$ (dd, $2 \mathrm{H}, J=9.7 \mathrm{~Hz}, 2.0 \mathrm{~Hz},), 6.63(\mathrm{~d}, 2 \mathrm{H}, J=2.0 \mathrm{~Hz}), 1.88(\mathrm{~s}, 3 \mathrm{H}) ;{ }^{13} \mathrm{C} \mathrm{NMR}\left(75 \mathrm{MHz}, \mathrm{CDCl}_{3}\right)$ : $\delta 172.60,168.75,161.03,160.78,138.82,134.65,131.78,122.84,121.30,118.66,118.29$, 114.30, 103.40, 20.25; HRMS (ESI ${ }^{+}$): calcd for $[\mathrm{M}+\mathrm{H}]^{+}, 319.09703$; found, 319.09652 .

\section{Synthesis of 9-[1-(4-Methoxycarbonylmethoxy-2-methylphenyl)]-6-hydroxy-3H-xanthen-3- one (4)}

To a mixture of $3(60 \mathrm{mg}, 0.18 \mathrm{mmol})$ and $\mathrm{Cs}_{2} \mathrm{CO}_{3}(400 \mathrm{mg}, 1.2 \mathrm{mmol})$ in dry dimethylformamide $(5 \mathrm{ml})$, methyl bromoacetate $(17 \mu \mathrm{l}, 0.18 \mathrm{mmol})$ was added. The reaction mixture was stirred at room temperature under argon overnight. The inorganic precipitate was filtered off and the filtrate was concentrated under reduced pressure. The residue was diluted with water and extracted with $\mathrm{CH}_{2} \mathrm{Cl}_{2}$ three times. The combined organic solution was washed with water and saturated aq. $\mathrm{NaCl}$, dried over $\mathrm{Na}_{2} \mathrm{SO}_{4}$ and evaporated. The residue was chromatographed on silica gel with $\mathrm{CH}_{2} \mathrm{Cl}_{2}-\mathrm{MeOH}(100: 5)$ as the eluent to give $\mathbf{4}$ as a red powder $(41.7 \mathrm{mg}, 57 \%) .{ }^{1} \mathrm{H}$ NMR $\left(300 \mathrm{MHz}, \mathrm{CDCl}_{3}\right): \delta 7.10(\mathrm{~d}, 1 \mathrm{H}, J=8.4 \mathrm{~Hz}), 7.08(\mathrm{~d}, 2 \mathrm{H}$, $J=9.2 \mathrm{~Hz}), 6.95(\mathrm{~d}, 1 \mathrm{H}, J=2.5 \mathrm{~Hz}), 6.89(\mathrm{dd}, 1 \mathrm{H}, J=8.4 \mathrm{~Hz}, 2.5 \mathrm{~Hz}), 6.84(\mathrm{~d}, 2 \mathrm{H}, J=2.0$ $\mathrm{Hz}), 6.80(\mathrm{dd}, 2 \mathrm{H}, J=9.2 \mathrm{~Hz}, 2.0 \mathrm{~Hz}), 4.73(\mathrm{~s}, 2 \mathrm{H}), 3.86(\mathrm{~s}, 3 \mathrm{H}), 2.03$ (s, 3H); HRMS (ESI ${ }^{+}$): calcd for $[\mathrm{M}+\mathrm{H}]^{+}, 391.11816$; found, 391.11455 .

\section{Synthesis of 9-[1-(4-Methoxycarbonylmethoxy-2-methylphenyl)]-6-hydroxy-3H-xanthen-3- one mono(2',3',4',6'-tetra-O-acetyl- $\beta$-D-galactopyranoside) (5)}

A mixture of 4 (39 mg, $0.1 \mathrm{mmol}), \mathrm{Cs}_{2} \mathrm{CO}_{3}(200 \mathrm{mg}, 0.6 \mathrm{mmol})$ and 2,3,4,6-tetra-O-acetyl- $\alpha$ D-galactopyranosyl bromide $(100 \mathrm{mg}, 0.25 \mathrm{mmol})$ in dry dimethylformamide $(2 \mathrm{ml})$ was stirred at room temperature under argon overnight. The inorganic precipitate was filtered off and the 
filtrate was concentrated under reduced pressure. The residue was diluted with water and extracted with $\mathrm{CH}_{2} \mathrm{Cl}_{2}$ three times. The combined organic solution was washed with water and saturated aq. $\mathrm{NaCl}$, dried over $\mathrm{Na}_{2} \mathrm{SO}_{4}$ and evaporated. The residue was chromatographed on silica gel with $\mathrm{CH}_{2} \mathrm{Cl}_{2}-\mathrm{MeOH}(100: 3)$ as the eluent to give 5 as an orange powder (41.8 $\mathrm{mg}$, $58 \%) .{ }^{1} \mathrm{H}$ NMR $\left(300 \mathrm{MHz}, \mathrm{CDCl}_{3}\right): \delta 7.10-6.80(\mathrm{~m}, 7 \mathrm{H}), 6.57(\mathrm{dd}, 1 \mathrm{H}, J=9.7 \mathrm{~Hz}, 1.9 \mathrm{~Hz})$, $6.40(\mathrm{~d}, 1 \mathrm{H}, J=1.9 \mathrm{~Hz}), 5.57-5.48(\mathrm{~m}, 2 \mathrm{H}), 5.18-5.12(\mathrm{~m}, 2 \mathrm{H}), 4.73(\mathrm{~s}, 2 \mathrm{H}), 4.22-4.16(\mathrm{~m}, 3 \mathrm{H})$, $3.87(\mathrm{~s}, 3 \mathrm{H}), 2.19(\mathrm{~s}, 3 \mathrm{H}), 2.13(\mathrm{~s}, 3 \mathrm{H}), 2.07(\mathrm{~s}, 3 \mathrm{H}), 2.03(\mathrm{~s}, 3 \mathrm{H}), 2.05(\mathrm{~s}, 3 \mathrm{H}) ; \mathrm{HRMS}\left(\mathrm{ESI}^{+}\right)$: calcd for $[\mathrm{M}+\mathrm{Na}]^{+}, 743.19519$; found, 743.19309 .

\section{Synthesis of 9-[1-(4-Methoxycarbonylmethoxy-2-methylphenyl)]-6-hydroxy-3H-xanthen-3- one mono- $\beta$-D-galactopyranoside (6)}

To a solution of $5(5 \mathrm{mg}, 6.9 \mu \mathrm{mol})$ in methanol $(2 \mathrm{ml})$, a $5 \mathrm{M}$ methanol solution of $\mathrm{NaOMe}$ $(2 \mu \mathrm{l}, 10 \mu \mathrm{mol})$ was added. The mixture was stirred at room temperature for 1 hour, then neutralized with Amberlite IR-120 $\left(\mathrm{H}^{+}\right)$. The Amberlite IR-120 was filtered off, and the filtrate was evaporated. The residue chromatographed on silica gel with $\mathrm{CHCl}_{3}-\mathrm{MeOH}(100: 10)$ as the eluent to give 6 as an orange powder $(2.4 \mathrm{mg}, 62 \%) .{ }^{1} \mathrm{H} \mathrm{NMR}\left(300 \mathrm{MHz}, \mathrm{CD}_{3} \mathrm{OD}\right): \delta 7.36$ $(\mathrm{d}, 1 \mathrm{H}, J=2.2 \mathrm{~Hz}), 7.18(\mathrm{~d}, 1 \mathrm{H}, J=9.0 \mathrm{~Hz}), 7.17(\mathrm{~d}, 1 \mathrm{H}, J=8.4 \mathrm{~Hz}), 7.15(\mathrm{~d}, 1 \mathrm{H}, J=9.6 \mathrm{~Hz})$, 7.07-7.12 (m, 1H), $7.06(\mathrm{~d}, 1 \mathrm{H}, J=2.6 \mathrm{~Hz}), 7.00(\mathrm{dd}, 1 \mathrm{H}, J=8.4,2.6 \mathrm{~Hz}), 6.61(\mathrm{dd}, 1 \mathrm{H}, J=$ 9.6, $2.0 \mathrm{~Hz}), 6.47(\mathrm{~d}, 1 \mathrm{H}, J=2.0 \mathrm{~Hz}), 5.10(\mathrm{dd}, 1 \mathrm{H}, J=7.7,2.6 \mathrm{~Hz}), 4.84(\mathrm{~s}, 2 \mathrm{H}), 3.92(\mathrm{~d}, 1 \mathrm{H}$, $J=3.5 \mathrm{~Hz}), 3.82(\mathrm{~s}, 3 \mathrm{H}), 3.73-3.89(\mathrm{~m}, 4 \mathrm{H}), 3.62(\mathrm{dd}, 1 \mathrm{H}, J=9.7,3.3 \mathrm{~Hz}), 2.03(\mathrm{~s}, 3 \mathrm{H})$; HRMS $\left(\mathrm{ESI}^{+}\right)$: calcd for $[\mathrm{M}+\mathrm{H}]^{+}, 553.17099$; found, 553.16771.

\section{Synthesis of 9-[1-(4-Carboxymethoxy-2-methylphenyl)]-6-hydroxy-3H-xanthen-3-one (7)}

To a solution of $4(15 \mathrm{mg}, 38 \mu \mathrm{mol})$ in methanol $(4 \mathrm{ml}), 2 \mathrm{M}$ aq.NaOH $1 \mathrm{ml}(2 \mathrm{mmol})$ was added. The mixture was stirred at room temperature for 4 hours, then neutralized with $2 \mathrm{~N}$ aq.HCl. The methanol was evaporated off, and the residue was diluted with $\mathrm{H}_{2} \mathrm{O}$ and extracted with $\mathrm{CH}_{2} \mathrm{Cl}_{2}$. The combined organic layer was evaporated, and the residue was chromatographed on silica gel with $\mathrm{CH}_{2} \mathrm{Cl}_{2}-\mathrm{MeOH}(100: 5)$ as the eluent to give 7 as an orange powder (12 mg, $83 \%) .{ }^{1} \mathrm{H}$ NMR (300 MHz, $\left.\mathrm{CD}_{3} \mathrm{OD}\right): \delta 7.00(\mathrm{~d}, 1 \mathrm{H}, J=8.4 \mathrm{~Hz}$ ), 6.93-6.88 $(\mathrm{m}, 2 \mathrm{H}), 6.88(\mathrm{~d}, 2 \mathrm{H}, J=9.0 \mathrm{~Hz}), 6.44(\mathrm{dd}, 2 \mathrm{H}, J=9.0,2.1 \mathrm{~Hz}), 6.41(\mathrm{~d}, 2 \mathrm{H}, J=2.1 \mathrm{~Hz}), 4.39$ (s, 2H), 1.92 (s, 3H). HRMS (ESI'): calcd for [M-H]', 375.08686; found, 375.08779.

\section{Synthesis of 2-Bromo-5-(toluene-4-sulfonyloxy)anisole (8)}

A mixture of 4-bromoresorcinol ( $2.0 \mathrm{~g}, 10.5 \mathrm{mmol})$, p-toluenesulfonyl chloride (2.21 g, 11.6 $\mathrm{mmol})$, and $\mathrm{K}_{2} \mathrm{CO}_{3}(4.4 \mathrm{~g}, 32 \mathrm{mmol})$ in dry acetone $(150 \mathrm{ml})$ was refluxed overnight. MeI (1.3 $\mathrm{ml}, 21 \mathrm{mmol}$ ) was added, and the reaction mixture was refluxed overnight again. The inorganic precipitate was filtered off and the filtrate was concentrated under reduced pressure. The residue was diluted with water and extracted with AcOEt three times. The combined organic solution was washed with water and saturated aq. $\mathrm{NaCl}$, dried over $\mathrm{Na}_{2} \mathrm{SO}_{4}$ and evaporated to give 8 as light pink oil (3.8 g, quant.). ${ }^{1} \mathrm{H}$ NMR (300 MHz, $\left.\mathrm{CDCl}_{3}\right): \delta 7.72(\mathrm{~d}, 2 \mathrm{H}, \boldsymbol{J}=8.3 \mathrm{~Hz}$ ), $7.40(\mathrm{~d}, 1 \mathrm{H}, J=8.6 \mathrm{~Hz}), 7.33(\mathrm{~d}, 2 \mathrm{H}, J=8.3 \mathrm{~Hz}), 6.59(\mathrm{~d}, 1 \mathrm{H}, J=2.5 \mathrm{~Hz}), 6.40(\mathrm{dd}, 1 \mathrm{H}, J=$ $8.6 \mathrm{~Hz}, 2.5 \mathrm{~Hz}), 3.78(\mathrm{~s}, 3 \mathrm{H}), 2.45(\mathrm{~s}, 3 \mathrm{H}) ;{ }^{13} \mathrm{C} \mathrm{NMR}\left(75 \mathrm{MHz}, \mathrm{CDCl}_{3}\right): \delta 156.47,156.25$, 133.04, 113.19, 105.06, 103.03, 56.08, 25.64, 18.19, -4.45; MS (EI): 356, $358\left(\mathrm{M}^{+}\right)$.

\section{Synthesis of 4-Bromo-3-methoxyphenol (9)}

To a solution of $8(3.08 \mathrm{~g}, 8.6 \mathrm{mmol})$ in dist $\mathrm{MeOH}(100 \mathrm{ml}), 2 \mathrm{~N}$ aq. $\mathrm{NaOH}(20 \mathrm{ml})$ was added. The solution was refluxed for $1.5 \mathrm{hrs}$, then the solvent was evaporated. The obtained residue was neutralized with $2 \mathrm{~N}$ aq. $\mathrm{HCl}$ and extracted with $\mathrm{CH}_{2} \mathrm{Cl}_{2}$ three times. The organic solution was washed with water and saturated aq. $\mathrm{NaCl}$, dried over $\mathrm{Na}_{2} \mathrm{SO}_{4}$ and evaporated to give $\mathbf{9}$ as clear oil $(1.57 \mathrm{~g}, 89 \%) .{ }^{1} \mathrm{H}$ NMR $\left(300 \mathrm{MHz}, \mathrm{CDCl}_{3}\right): \delta 7.34(\mathrm{~d}, 1 \mathrm{H}, J=8.6 \mathrm{~Hz}), 6.45(\mathrm{~d}, 1 \mathrm{H}$, $J=2.7 \mathrm{~Hz}), 6.32(\mathrm{dd}, 1 \mathrm{H}, J=8.6 \mathrm{~Hz}, 2.7 \mathrm{~Hz}), 3.86(\mathrm{~s}, 3 \mathrm{H}) ; \mathrm{MS}(\mathrm{EI}): 202,204\left(\mathrm{M}^{+}\right)$. 


\section{Synthesis of 2-Bromo-5-(tert-butyldimethylsilyloxy)anisole (10)}

A mixture of $9(1.57 \mathrm{~g}, 7.7 \mathrm{mmol})$, TBDMS-Cl (3.5 g, $23 \mathrm{mmol})$, and imidazole (2.6 g, 39 $\mathrm{mmol})$ in dry DMF $(10 \mathrm{ml})$ was stirred at room temperature under argon overnight. The solvent was concentrated under reduced pressure. The residue was diluted with water and extracted with $\mathrm{CH}_{2} \mathrm{Cl}_{2}$ three times. The combined organic solution was washed with water and saturated aq. $\mathrm{NaCl}$, dried over $\mathrm{Na}_{2} \mathrm{SO}_{4}$ and evaporated. The residue was chromatographed on silica gel with hexane-AcOEt (4:1) as the eluent to give $\mathbf{1 0}$ as a light yellow clear oil $(1.88 \mathrm{~g}, 76.7$ \%). ${ }^{1} \mathrm{H}$ NMR (300 MHz, $\left.\mathrm{CDCl}_{3}\right): \delta 7.33(\mathrm{~d}, 1 \mathrm{H}, J=8.6 \mathrm{~Hz}), 6.41(\mathrm{~d}, 1 \mathrm{H}, J=2.6 \mathrm{~Hz}), 6.34$ $(\mathrm{dd}, 1 \mathrm{H}, J=8.6 \mathrm{~Hz}, 2.6 \mathrm{~Hz}), 3.85(\mathrm{~s}, 3 \mathrm{H}), 0.98(\mathrm{~s}, 9 \mathrm{H}), 0.20(\mathrm{~s}, 6 \mathrm{H}) ;{ }^{13} \mathrm{C}$ NMR $(75 \mathrm{MHz}$, $\left.\mathrm{CDCl}_{3}\right): \delta 156.46,149.55,145.61,133.28,132.03,129.80,128.59,115.20,109.92,106.97$, 56.34, 21.70; MS (EI): 316, $318\left(\mathrm{M}^{+}\right)$.

\section{Synthesis of 9-\{1-[4-(tert-Butyldimethylsilyloxy)-2-methoxyphenyl]\}-6-hydroxy-3H- xanthen-3-one (11)}

$10(1.39 \mathrm{~g}, 4.4 \mathrm{mmol})$ was dissolved in distilled THF $(10 \mathrm{ml})$ and the solution was cooled to $-78{ }^{\circ} \mathrm{C}$ (dry ice-acetone). tert-Butyllithium in n-pentane solution $(4.5 \mathrm{ml}, 6.57 \mathrm{mmol})$ was added dropwise to the reaction mixture, then 3,6-bis-( $t$-butyldimethylsilanyloxy)xanthen-9one $(1.19 \mathrm{~g}, 2.6 \mathrm{mmol})$ dissolved in dist THF $20 \mathrm{ml}$ was further added dropwise. The mixture was stirred at $-78{ }^{\circ} \mathrm{C}$ under argon for $30 \mathrm{~min}$, and $2 \mathrm{~N}$ aq. $\mathrm{HCl}$ was added. The solvent was evaporated under reduced pressure to leave a residue, which was diluted with water and extracted with $\mathrm{CH}_{2} \mathrm{Cl}_{2}$ three times. The combined organic solution was washed with water and saturated aq. $\mathrm{NaCl}$, dried over $\mathrm{Na}_{2} \mathrm{SO}_{4}$ and evaporated. The precipitate was chromatographed on silica gel with $\mathrm{CH}_{2} \mathrm{Cl}_{2}-\mathrm{MeOH}(100: 5)$ as the eluent to give $\mathbf{1 1}$ as an orange powder (43.6 $\mathrm{mg}, 3.7 \%) .{ }^{1} \mathrm{H}$ NMR $\left(300 \mathrm{MHz}, \mathrm{CDCl}_{3}\right): \delta 7.18(\mathrm{~d}, 2 \mathrm{H}, J=9.0 \mathrm{~Hz}), 7.02(\mathrm{~d}, 1 \mathrm{H}, J=8.3 \mathrm{~Hz})$, 6.80-6.75 (m, 4H), 6.60 (dd, $1 \mathrm{H}, J=8.3 \mathrm{~Hz}, 2.0 \mathrm{~Hz}), 6.56(\mathrm{~d}, 1 \mathrm{H}, J=2.0 \mathrm{~Hz}), 3.67(\mathrm{~s}, 3 \mathrm{H})$, $1.04(\mathrm{~s}, 9 \mathrm{H}), 0.31$ (s, 6H); HRMS $\left(\mathrm{ESI}^{+}\right)$: calcd for $[\mathrm{M}+\mathrm{H}]^{+}, 449.17842$; found, 449.17790 .

\section{Synthesis of 9-[1-(4-Hydroxy-2-methoxyphenyl)]-6-hydroxy-3H-xanthen-3-one (12)}

To a solution of 11 (43.6 mg, $97 \mu \mathrm{mol}), 2 \mathrm{~N}$ aq. $\mathrm{HCl}(2 \mathrm{ml})$ was added, and the mixture was refluxed for $5 \mathrm{hrs}$. The solvent was evaporated under reduced pressure. The obtained residue was chromatographed on silica gel with $\mathrm{CH}_{2} \mathrm{Cl}_{2}-\mathrm{MeOH}(100: 5)$ as the eluent to give $\mathbf{1 2}$ as a red powder $(22.7 \mathrm{mg}, 70 \%)$. ${ }^{1} \mathrm{H}$ NMR $\left(300 \mathrm{MHz}, \mathrm{CD}_{3} \mathrm{OD}\right): \delta 7.82(\mathrm{~d}, 2 \mathrm{H}, J=9.2 \mathrm{~Hz}), 7.32$ $(\mathrm{d}, 2 \mathrm{H}, J=2.4 \mathrm{~Hz}), 7.24(\mathrm{dd}, 2 \mathrm{H}, J=9.2 \mathrm{~Hz}, 2.4 \mathrm{~Hz}), 7.18(\mathrm{~d}, 1 \mathrm{H}, J-8.3 \mathrm{~Hz}), 6.76(\mathrm{~d}, 1 \mathrm{H}, J$ $=2.0 \mathrm{~Hz}), 6.70(\mathrm{dd}, 1 \mathrm{H}, J=8.3 \mathrm{~Hz}, 2.0 \mathrm{~Hz}), 3.70(\mathrm{~s}, 3 \mathrm{H}) ; \mathrm{HRMS}\left(\mathrm{ESI}^{+}\right)$: calcd for $[\mathrm{M}+\mathrm{H}]^{+}$, 335.09195; found, 335.08862 .

\section{Synthesis of 9-[1-(2-Methoxy-4-methoxycarbonylmethoxyphenyl)]-6-hydroxy-3H-xanthen-3- one (13)}

A mixture of $12(22.7 \mathrm{mg}, 68 \mu \mathrm{mol})$, bromomethyl acetate $(6.27 \mu \mathrm{l}, 68 \mu \mathrm{mol})$, and $\mathrm{Cs}_{2} \mathrm{CO}_{3}$ $(66.5 \mathrm{mg}, 204 \mu \mathrm{mol})$ was stirred at room temperature under argon overnight. The inorganic precipitate was filtered off and the filtrate was concentrated under reduced pressure. The residue was diluted with water and extracted with $\mathrm{CH}_{2} \mathrm{Cl}_{2}$ three times. The combined organic solution was washed with water and saturated aq. $\mathrm{NaCl}$, dried over $\mathrm{Na}_{2} \mathrm{SO}_{4}$ and evaporated. The residue was chromatographed on silica gel with $\mathrm{CH}_{2} \mathrm{Cl}_{2}-\mathrm{MeOH}$ (100:5) as the eluent to give 13 as an orange powder $(17.4 \mathrm{mg}, 63 \%) .{ }^{1} \mathrm{H} \mathrm{NMR}\left(300 \mathrm{MHz}, \mathrm{CDCl}_{3}\right): \delta 7.16(\mathrm{~d}, 2 \mathrm{H}, J$ $=9.0 \mathrm{~Hz}), 7.10(\mathrm{~d}, 1 \mathrm{H}, J=8.3 \mathrm{~Hz}), 6.81(\mathrm{~m}, 3 \mathrm{H}), 6.75(\mathrm{dd}, 2 \mathrm{H}, J=9.0 \mathrm{~Hz}, 2.0 \mathrm{~Hz}), 6.59(\mathrm{dd}$, $1 \mathrm{H}, J=8.3 \mathrm{~Hz}, 2.2 \mathrm{~Hz},), 4.74(\mathrm{~s}, 2 \mathrm{H}), 3.87(\mathrm{~s}, 3 \mathrm{H}), 3.69$ (s, 3H); HRMS $\left(\mathrm{ESI}^{+}\right)$: calcd for [M $+\mathrm{H}]^{+}, 407.11308$; found, 407.11006 . 
Synthesis of 9-[1-(2-Methoxy-4-methoxycarbonylmethoxyphenyl)]-6-hydroxy-3H-xanthen-3one mono(2',3',4',6'-tetra-O-acetyl- $\beta$-D-galactopyranoside)(14)

A mixture of $\mathbf{1 3}$ ( $3.8 \mathrm{mg}, 9.3 \mu \mathrm{mol}), \mathrm{Cs}_{2} \mathrm{CO}_{3}(38.4 \mathrm{mg}, 117 \mu \mathrm{mol}$ ), and 2,3,4,6-tetra-O-acetyl$\alpha$-D-galactopyranosyl bromide (100 $\mathrm{mg}, 0.25 \mathrm{mmol})$ in dry DMF $(2 \mathrm{ml})$ was stirred at room temperature under argon for $4.5 \mathrm{hrs}$. The inorganic precipitate was filtered off and the filtrate was concentrated under reduced pressure. The residue was diluted with water and extracted with $\mathrm{CH}_{2} \mathrm{Cl}_{2}$ three times. The combined organic solution was washed with water and saturated aq. $\mathrm{NaCl}$, dried over $\mathrm{Na}_{2} \mathrm{SO}_{4}$, and evaporated. The residue was chromatographed on silica gel with $\mathrm{CH}_{2} \mathrm{Cl}_{2}-\mathrm{MeOH}(100: 3)$ as the eluent to give $\mathbf{1 4}$ as an orange powder $(6.4 \mathrm{mg}, 94.2$

\%). ${ }^{1} \mathrm{H}$ NMR $\left(300 \mathrm{MHz}, \mathrm{CDCl}_{3}\right): \delta 7.13-7.06(\mathrm{~m}, 4 \mathrm{H}), 6.81(\mathrm{dd}, 1 \mathrm{H}, J=8.8 \mathrm{~Hz}, 2.4 \mathrm{~Hz}), 6.74$ $(\mathrm{d}, 1 \mathrm{H}, J=2.3 \mathrm{~Hz}), 6.59(\mathrm{dd}, 1 \mathrm{H}, J=8.2 \mathrm{~Hz}, 2.3 \mathrm{~Hz}), 6.57(\mathrm{dd}, 1 \mathrm{H}, J=9.7 \mathrm{~Hz}, 1.8 \mathrm{~Hz}), 6.39$ $(\mathrm{d}, 1 \mathrm{H}, J=1.8 \mathrm{~Hz}), 5.56-5.49(\mathrm{~m}, 2 \mathrm{H}), 5.18-5.13(\mathrm{~m}, 2 \mathrm{H}), 4.74(\mathrm{~s}, 2 \mathrm{H}), 4.25-4.17(\mathrm{~m}, 3 \mathrm{H})$, $3.86(\mathrm{~s}, 3 \mathrm{H}), 3.70(\mathrm{~s}, 3 \mathrm{H}), 2.20(\mathrm{~s}, 3 \mathrm{H}), 2.14(\mathrm{~s}, 3 \mathrm{H}), 2.07(\mathrm{~s}, 3 \mathrm{H}), 2.03(\mathrm{~s}, 3 \mathrm{H})$; HRMS $\left(\mathrm{ESI}^{+}\right)$: calcd for $[\mathrm{M}+\mathrm{H}]^{+}, 737.20816$; found, 737.20860.

\section{Synthesis of 9-[1-(2-Methoxy-4-methoxycarbonylmethoxyphenyl)]-6-hydroxy-3H-xanthen-3- one mono- $\beta$-D-galactopyranoside)(15)}

To a solution of $\mathbf{1 4}(2 \mathrm{mg}, 2.7 \mu \mathrm{mol})$ in methanol $(1 \mathrm{ml})$, a $5 \mathrm{M}$ methanol solution of $\mathrm{NaOMe}$ $(2 \mu \mathrm{l}, 5 \mu \mathrm{mol})$ was added. The mixture was stirred at room temperature for 1 hour, then neutralized with Amberlite IR-120 $\left(\mathrm{H}^{+}\right)$. The Amberlite IR-120 was filtered off, and the filtrate was evaporated. The residue chromatographed on silica gel with $\mathrm{CHCl}_{3}-\mathrm{MeOH}(100: 10)$ as the eluent to give 15 as an orange powder $(0.74 \mathrm{mg}, 48 \%)$. ${ }^{1} \mathrm{H}$ NMR (400 MHz, $\left.\mathrm{CD}_{3} \mathrm{OD}\right): \delta$ $7.35(\mathrm{~d}, 1 \mathrm{H}, J=2.4 \mathrm{~Hz}), 7.30(\mathrm{~d}, 1 \mathrm{H}, J=9.3 \mathrm{~Hz}), 7.27(\mathrm{~d}, 1 \mathrm{H}, J=9.8 \mathrm{~Hz}), 7.19(\mathrm{~d}, 1 \mathrm{H}, J=$ $8.3 \mathrm{~Hz}), 7.11(\mathrm{dd}, 1 \mathrm{H}, J=9.3,2.4 \mathrm{~Hz}), 6.88(\mathrm{~d}, 1 \mathrm{H}, J=2.2 \mathrm{~Hz}), 6.77(\mathrm{dd}, 1 \mathrm{H}, J=8.3,2.2 \mathrm{~Hz})$, $6.62(\mathrm{dd}, 1 \mathrm{H}, J=9.8,2.0 \mathrm{~Hz}), 6.46(\mathrm{~d}, 1 \mathrm{H}, J=2.0 \mathrm{~Hz}), 5.10(\mathrm{dd}, 1 \mathrm{H}, J=7.3,1.5 \mathrm{~Hz}), 4.78(\mathrm{~s}$, $2 \mathrm{H}), 3.93(\mathrm{~d}, 1 \mathrm{H}, J=2.4 \mathrm{~Hz}), 3.89-3.75(\mathrm{~m}, 4 \mathrm{H}), 3.73(\mathrm{~s}, 3 \mathrm{H}), 3.70-3.69(\mathrm{~m}, 1 \mathrm{H}), 3.65(\mathrm{~s}, 3 \mathrm{H})$. HRMS $\left(\mathrm{ESI}^{+}\right)$: calcd for $[\mathrm{M}+\mathrm{H}]^{+}, 569.16590$; found, 569.16846 .

\section{Synthesis of 9-[1-(4-Carboxymethoxy-2-methoxyphenyl)]-6-hydroxy-3H-xanthen-3-one (16)}

To a solution of $\mathbf{1 3}(4.1 \mathrm{mg}, 10 \mu \mathrm{mol})$ in methanol $(1 \mathrm{ml}), 2 \mathrm{~N}$ aq. $\mathrm{NaOH} 0.1 \mathrm{ml}(0.2 \mathrm{mmol})$ was added. The mixture was stirred at room temperature for 4 hours, then neutralized with 2 $\mathrm{N}$ aq.HCl. The solvent was evaporated off, and the residue was subjected to reverse-phase preparative TLC (RP18W) with acetonitrile/water (1:1) as the eluent to give $\mathbf{1 6}$ as an orange powder (3 mg, $76 \%) .{ }^{1} \mathrm{H}$ NMR $\left(300 \mathrm{MHz}, \mathrm{CD}_{3} \mathrm{OD}\right): \delta 7.25(\mathrm{~d}, 2 \mathrm{H}, J=9.17 \mathrm{~Hz}), 7.12(\mathrm{~d}, 1 \mathrm{H}$, $J=8.25 \mathrm{~Hz}), 6.84(\mathrm{~d}, 1 \mathrm{H}, J=2.20 \mathrm{~Hz}), 6.74(\mathrm{dd}, 1 \mathrm{H}, J=8.25,2.20 \mathrm{~Hz}), 6.66-6.72(\mathrm{~m}, 4 \mathrm{H})$, $4.52(\mathrm{~s}, 2 \mathrm{H}), 3.73(\mathrm{~s}, 3 \mathrm{H})$; HRMS (ESI'): calcd for [M-H]', 391.08178; found, 391.07947.

\section{Synthesis of 9-\{1-[4-(4-Methoxycarbonylbutyloxy)-2-methylphenyl]\}-6-hydroxy-3H- xanthen-3-one (17)}

To a mixture of $363.8 \mathrm{mg}(0.20 \mathrm{mmol})$ and $\mathrm{Cs}_{2} \mathrm{CO}_{3} 400 \mathrm{mg}(1.2 \mathrm{mmol})$ in dry dimethylformamide $(2 \mathrm{ml})$, methyl 5 -bromovalerate $(21 \mu \mathrm{l}, 0.18 \mathrm{mmol})$ was added. The reaction mixture was stirred at room temperature under argon overnight. The inorganic precipitate was filtered off and the filtrate was concentrated under reduced pressure. The residue was diluted with water and extracted with $\mathrm{CH}_{2} \mathrm{Cl}_{2}$ three times. The combined organic solution was washed with water and saturated aq. $\mathrm{NaCl}$, dried over $\mathrm{Na}_{2} \mathrm{SO}_{4}$ and evaporated. The residue was chromatographed on silica gel with $\mathrm{CH}_{2} \mathrm{Cl}_{2}-\mathrm{MeOH}$ (100:5) as the eluent to give 17 as a red powder $(53.7 \mathrm{mg}, 62 \%) .{ }^{1} \mathrm{H}$ NMR $\left(300 \mathrm{MHz}, \mathrm{CDCl}_{3}\right): \delta 7.10(\mathrm{~d}, 2 \mathrm{H}, J=9.2$ $\mathrm{Hz}), 7.07(\mathrm{~d}, 1 \mathrm{H}, J=8.3 \mathrm{~Hz}), 6.91-6.84(\mathrm{~m}, 4 \mathrm{H}), 6.81(\mathrm{dd}, 2 \mathrm{H}, J=9.2 \mathrm{~Hz}, 2.0 \mathrm{~Hz}), 4.06(\mathrm{~m}$, $2 \mathrm{H}), 3.70(\mathrm{~s}, 3 \mathrm{H}), 2.45(\mathrm{~m}, 2 \mathrm{H}), 2.02(\mathrm{~s}, 3 \mathrm{H}), 1.88(\mathrm{~m}, 4 \mathrm{H}) ;{ }^{13} \mathrm{CNMR}\left(75 \mathrm{MHz}, \mathrm{CDCl}_{3}\right): \delta 175.04$, $174.08,159.73,157.43,152.90,137.67,130.77,130.21,124.47,121.80,116.42,115.57$, 
$111.84,103.68,67.41,53.35,33.58,28.54,21.55,19.83$; HRMS $\left(\mathrm{ESI}^{+}\right)$: calcd for $[\mathrm{M}+\mathrm{H}]^{+}$, 433.16511; found, 433.16853 .

\section{Synthesis of 9-\{1-[4-(4-methoxycarbonylbutyloxy)-2-methylphenyl]\}-6-hydroxy-3H- xanthen-3-one Mono(2',3',4',6'-tetra-O-acetyl- $\beta$-D-galactopyranoside) (18)}

A mixture of 17 (18.2 mg, $42 \mu \mathrm{mol}), \mathrm{Cs}_{2} \mathrm{CO}_{3}(250 \mathrm{mg}, 0.77 \mathrm{mmol})$ and 2,3,4,6-tetra-O-acetyl$\alpha$-D-galactopyranosyl bromide $(100 \mathrm{mg}, 0.25 \mathrm{mmol})$ in dry dimethylformamide $(1 \mathrm{ml})$ was stirred at room temperature under argon overnight. The inorganic precipitate was filtered off and the filtrate was concentrated under reduced pressure. The residue was diluted with water and extracted with $\mathrm{CH}_{2} \mathrm{Cl}_{2}$ three times. The combined organic solution was washed with water and saturated aq. $\mathrm{NaCl}$, dried over $\mathrm{Na}_{2} \mathrm{SO}_{4}$ and evaporated. The residue was chromatographed on silica gel with AcOEt as the eluent to give $\mathbf{1 8}$ as an orange powder $(25 \mathrm{mg}, 78 \%) .{ }^{1} \mathrm{H}$ NMR $\left(300 \mathrm{MHz}, \mathrm{CDCl}_{3}\right): \delta 7.08-6.80(\mathrm{~m}, 7 \mathrm{H}), 6.57(\mathrm{dd}, 1 \mathrm{H}, J=9.7 \mathrm{~Hz}, 2.0 \mathrm{~Hz}), 6.39(\mathrm{~d}, 1 \mathrm{H}, J=$ $2.0 \mathrm{~Hz}), 5.56-5.48(\mathrm{~m}, 2 \mathrm{H}), 5,18-5.12(\mathrm{~m}, 2 \mathrm{H}), 4.22-4.11(\mathrm{~m}, 3 \mathrm{H}), 4.06(\mathrm{~m}, 2 \mathrm{H}), 3.70(\mathrm{~s}, 3 \mathrm{H})$, $2.19(\mathrm{~s}, 3 \mathrm{H}), 2.13(\mathrm{~s}, 3 \mathrm{H}), 2.07(\mathrm{~s}, 3 \mathrm{H}), 2.03(\mathrm{~s}, 3 \mathrm{H}), 1.88(\mathrm{~m}, 4 \mathrm{H})$; HRMS $\left(\mathrm{ESI}^{+}\right)$: calcd for [M $+\mathrm{H}]^{+}, 763.26019$; found, 763.25543 .

\section{Synthesis of 9-\{1-[4-(4-methoxycarbonylbutyloxy)-2-methylphenyl]\}-6-hydroxy-3H-

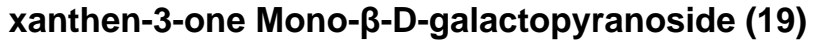

To a solution of $\mathbf{1 8}(28 \mathrm{mg}, 37 \mu \mathrm{mol})$ in methanol $(5 \mathrm{ml})$, a $5 \mathrm{M}$ methanol solution of $\mathrm{NaOMe}$ $(10 \mu \mathrm{l}, 50 \mu \mathrm{mol})$ was added. The mixture was stirred at room temperature for 1 hour, then neutralized with Amberlite IR-120 $\left(\mathrm{H}^{+}\right)$. The Amberlite IR-120 was filtered off, and the filtrate was evaporated. The residue was subjected to reverse-phase preparative TLC (RP18W) with acetonitrile/water (1:1) as the eluent to give 19 as an orange powder (7.4 mg, $34 \%) .{ }^{1} \mathrm{H}$ NMR (300 MHz, CD $3 \mathrm{OD}): \delta 7.37(\mathrm{~d}, J=2.4 \mathrm{~Hz}, 1 \mathrm{H}), 7.19(\mathrm{~d}, \mathrm{~J}=8.8 \mathrm{~Hz}, 1 \mathrm{H}), 7.16(\mathrm{~d}, \mathrm{~J}=9.7 \mathrm{~Hz}$, $1 \mathrm{H}), 7.15(\mathrm{~d}, \mathrm{~J}=8.3 \mathrm{~Hz}, 1 \mathrm{H}), 7.10(\mathrm{~d}, \mathrm{~J}=8.3 \mathrm{~Hz}, 2.4 \mathrm{~Hz}, 1 \mathrm{H}), 7.03(\mathrm{~d}, \mathrm{~J}=1.8 \mathrm{~Hz}, 1 \mathrm{H}), 6.99$ $(\mathrm{dd}, \mathrm{J}=8.3 \mathrm{~Hz}, 1.8 \mathrm{~Hz}, 1 \mathrm{H}), 6.61(\mathrm{dd}, \mathrm{J}=9.7 \mathrm{~Hz}, 2.0 \mathrm{~Hz}, 1 \mathrm{H}), 6.47(\mathrm{~d}, \mathrm{~J}=2.0 \mathrm{~Hz}, 1 \mathrm{H}), 4.10$ $(\mathrm{m}, 2 \mathrm{H}), 5.10(\mathrm{dd}, 7.7 \mathrm{~Hz}, 3.0 \mathrm{~Hz}, 1 \mathrm{H}), 3.92(\mathrm{~d}, \mathrm{~J}=3.5 \mathrm{~Hz}, 1 \mathrm{H}), 3.88-3.74(\mathrm{~m}, 4 \mathrm{H}), 3.62(\mathrm{dd}$, $9.5 \mathrm{~Hz}, 3.1 \mathrm{~Hz}, 1 \mathrm{H}), 3.67(\mathrm{~s}, 3 \mathrm{H}), 2.45(\mathrm{~m}, 2 \mathrm{H}), 2.06(\mathrm{~s}, 3 \mathrm{H}), 1.88(\mathrm{~m}, 4 \mathrm{H})$; HRMS $\left(\mathrm{ESI}^{+}\right)$: calcd for $[\mathrm{M}+\mathrm{H}]^{+}$, 595.21794; found, 595.21862.

\section{Synthesis of 9-\{1-[4-(4-Carboxybutyloxy)-2-methylphenyl]\}-6-hydroxy-3H-xanthen-3-one (20)}

To a solution of $\mathbf{1 7}(9.3 \mathrm{mg}, 21.5 \mu \mathrm{mol})$ in methanol ( $2 \mathrm{ml}), 2 \mathrm{M}$ aq. $\mathrm{NaOH} 0.5 \mathrm{ml}(1 \mathrm{mmol})$ was added. The mixture was stirred at room temperature for 4 hours, then neutralized with 2 $\mathrm{N}$ aq.HCl. The methanol was evaporated off, and the residue was diluted with $\mathrm{H}_{2} \mathrm{O}$, then extracted with $\mathrm{CH}_{2} \mathrm{Cl}_{2}$. The combined organic layer was evaporated, and the residue was chromatographed on silica gel with $\mathrm{CH}_{2} \mathrm{Cl}_{2}-\mathrm{MeOH}(100: 5)$ as the eluent to give $\mathbf{2 0}$ as an orange powder (7 mg, $78 \%)$. ${ }^{1} \mathrm{H}$ NMR (300 MHz, $\left.\mathrm{CD}_{3} \mathrm{OD}\right): \delta 7.11-7.16(\mathrm{~m}, 3 \mathrm{H}), 7.03(\mathrm{~d}, 1 \mathrm{H}, J=2.6$ $\mathrm{Hz}), 6.98(\mathrm{dd}, 1 \mathrm{H}, J=8.4,2.6 \mathrm{~Hz}), 6.70-6.75(\mathrm{~m}, 4 \mathrm{H}), 4.10(\mathrm{t}, 2 \mathrm{H}, J=5.6 \mathrm{~Hz}), 2.40(\mathrm{t}, 2 \mathrm{H}, J$ $=6.8 \mathrm{~Hz}), 2.02(\mathrm{~s}, 3 \mathrm{H}), 1.92-1.78(\mathrm{~m}, 4 \mathrm{H})$; HRMS $\left(\mathrm{ESI}^{-}\right)$: calcd for $[\mathrm{M}-\mathrm{H}]^{-}, 417.13381$; found, 417.13084 .

\section{Synthesis of 9-\{1-[4-(4-Carboxybutyloxy)-2-methylphenyl]\}-6-hydroxy-3H-xanthen-3-one mono(2',3',4',6'-tetra-O-acetyl- $\beta$-D-galactopyranoside) (21)}

To a solution of $18(37.7 \mathrm{mg}, 0.049 \mathrm{mmol})$ in methanol/water $(1.5 \mathrm{ml}: 0.5 \mathrm{ml}), 2 \mathrm{M}$ aq. $\mathrm{NaOH}$ $1 \mathrm{ml}(2 \mathrm{mmol})$ was added. The mixture was stirred at $0{ }^{\circ} \mathrm{C}$ for 30 minutes, then neutralized with Amberlite IR-120 $\left(\mathrm{H}^{+}\right)$. The Amberlite IR-120 was filtered off, and the filtrate was evaporated. The residue was subjected to reverse-phase preparative TLC (RP18W) with acetonitrile/water (1:1) as the eluent to give 21 as an orange powder $(15.1 \mathrm{mg}, 53 \%) .{ }^{1} \mathrm{H}$ NMR $\left(300 \mathrm{MHz}, \mathrm{CD}_{3} \mathrm{OD}\right): \delta 7.26(\mathrm{~d}, 1 \mathrm{H}, J=2.2 \mathrm{~Hz}), 7.11(\mathrm{~d}, 1 \mathrm{H}, J=8.5 \mathrm{~Hz}), 7.08(\mathrm{~d}, 1 \mathrm{H}, J=9.6$ 
$\mathrm{Hz}), 7.03(\mathrm{~d}, 1 \mathrm{H}, J=8.2 \mathrm{~Hz}), 7.02(\mathrm{dd}, 1 \mathrm{H}, J=8.5 \mathrm{~Hz}, 2.2 \mathrm{~Hz}), 6.94(\mathrm{~d}, 1 \mathrm{H}, J=2.3 \mathrm{~Hz}), 6.89$ $(\mathrm{dd}, 1 \mathrm{H}, J=8.2 \mathrm{~Hz}, 2.3 \mathrm{~Hz}), 6.53(\mathrm{dd}, 1 \mathrm{H}, J=9.6 \mathrm{~Hz}, 2.0 \mathrm{~Hz}), 6.37$ (d, $1 \mathrm{H}, J=2.0 \mathrm{~Hz}), 4.01$ $(\mathrm{m}, 2 \mathrm{H}), 5.00(\mathrm{dd}, 1 \mathrm{H}, J=7.7 \mathrm{~Hz}, 2.6 \mathrm{~Hz}), 3.83(\mathrm{~d}, 1 \mathrm{H}, J=3.3 \mathrm{~Hz}), 3.82-3.64(\mathrm{~m}, 4 \mathrm{H}), 3.53$ $(\mathrm{dd}, 1 \mathrm{H}, J=9.7 \mathrm{~Hz}, 3.3 \mathrm{~Hz}), 2.17(\mathrm{~m}, 2 \mathrm{H}), 1.93(\mathrm{~s}, 3 \mathrm{H}), 1.74(\mathrm{~m}, 4 \mathrm{H})$; HRMS $\left(\mathrm{ESI}^{+}\right)$: calcd for $[\mathrm{M}+\mathrm{Na}]^{+}, 603.18423$; found, 603.18242.

\section{Synthesis of 9-\{1-[4-(4-acetoxymethoxycarbonylbutyloxy)-2-methylphenyl]\}-6-hydroxy-3H- xanthen-3-one mono- $\beta$-D-galactopyranoside (22)}

To a solution of $\mathbf{2 1}(10 \mathrm{mg}, 17.2 \mu \mathrm{mol})$ in methanol/acetonitrile $(1 \mathrm{ml}: 2 \mathrm{ml})$, a solution of bromomethyl acetate $(68.5 \mu \mathrm{l}, 690 \mu \mathrm{mol})$ and $\mathrm{N}, \mathrm{N}$-diisopropylethylamine $(22.3 \mu \mathrm{l}, 130 \mu \mathrm{mol})$ in acetonitrile $(2 \mathrm{ml})$ was added slowly. The mixture was stirred at room temperature under argon for $10 \mathrm{hrs}$, then concentrated under reduced pressure. The residue was purified by semipreparative reverse-phase HPLC using eluent A (100 mM triethylammonium acetate buffer, $\mathrm{pH} 6.5)$ and eluent $\mathrm{B}$ (acetonitrile) $(\mathrm{A} / \mathrm{B}=65 / 35)$ to give 22 as an orange powder (10.9 $\mathrm{mg}, 97$ \%). ${ }^{1} \mathrm{H}$ NMR $\left(300 \mathrm{MHz}, \mathrm{CD}_{3} \mathrm{OD}\right): \delta 7.28(\mathrm{~d}, 1 \mathrm{H}, J=2.2 \mathrm{~Hz}), 7.13-6.88(\mathrm{~m}, 6 \mathrm{H}), 6.53(\mathrm{dd}$, $1 \mathrm{H}, J=9.7 \mathrm{~Hz}, 2.0 \mathrm{~Hz}), 6.38(\mathrm{dd}, 1 \mathrm{H}, J=2.0 \mathrm{~Hz}), 5.65(\mathrm{~s}, 2 \mathrm{H}), 4.02(\mathrm{~m}, 2 \mathrm{H}), 5.01(\mathrm{dd}, 1 \mathrm{H}$, $J=8.1 \mathrm{~Hz}, 2.8 \mathrm{~Hz}), 3.83(\mathrm{~d}, 1 \mathrm{H}, J=3.1 \mathrm{~Hz}), 3.79-3.65(\mathrm{~m}, 4 \mathrm{H}), 3.53(\mathrm{dd}, 1 \mathrm{H}, J=9.5 \mathrm{~Hz}, 3.6$ $\mathrm{Hz}), 2.42(\mathrm{~m}, 2 \mathrm{H}), 1.99(\mathrm{~s}, 3 \mathrm{H}), 1.94(\mathrm{~s}, 3 \mathrm{H}), 1.78(\mathrm{~m}, 4 \mathrm{H}) ; \mathrm{HRMS}\left(\mathrm{ESI}^{+}\right)$: calcd for [M $+\mathrm{Na}]^{+}, 675.20536$; found, 675.20359.

\section{Synthesis of 9-\{1-[4-(4-acetoxymethoxycarbonylbutyloxy)-2-methylphenyl]\}-6-hydroxy-3H- xanthen-3-one (23)}

To a solution of $\mathbf{2 0}(2.8 \mathrm{mg}, 6.7 \mu \mathrm{mol})$ in dimethylformamide $(0.5 \mathrm{ml})$, a solution of bromomethyl acetate $(6.8 \mu \mathrm{l}, 69 \mu \mathrm{mol})$ and $\mathrm{N}, \mathrm{N}$-diisopropylethylamine $(2.2 \mu \mathrm{l}, 13 \mu \mathrm{mol})$ in dimethylformamide $(0.5 \mathrm{ml})$ was added. The mixture was stirred at room temperature under argon overnight, then diluted with $\mathrm{H}_{2} \mathrm{O}$, and extracted with ethyl acetate. The combined organic layer was concentrated under reduced pressure. The residue was purified by semi-preparative reverse-phase HPLC with a linear gradient of eluent A (100 mM triethylammonium acetate buffer, pH 6.5) and eluent B (acetonitrile) (initial: $70 \%$ A / $30 \%$ B, final (20 minutes): $30 \%$ A / $70 \%$ B) to give 23 as an orange powder $(0.88 \mathrm{mg}, 27 \%) .{ }^{1} \mathrm{H} \mathrm{NMR}\left(300 \mathrm{MHz}, \mathrm{CD}_{3} \mathrm{OD}\right)$ : $\delta 7.11(\mathrm{~d}, 1 \mathrm{H}, J=8.3 \mathrm{~Hz}), 7.00-7.05(\mathrm{~m}, 3 \mathrm{H}), 6.97(\mathrm{dd}, 1 \mathrm{H}, J=8.3,2.5 \mathrm{~Hz}), 6.59-6.64(\mathrm{~m}$, $4 \mathrm{H}), 5.48(\mathrm{~s}, 2 \mathrm{H}), 4.11(\mathrm{t}, 2 \mathrm{H}, J=5.3 \mathrm{~Hz}), 2.50(\mathrm{t}, 2 \mathrm{H}, J=6.6 \mathrm{~Hz}), 2.07(\mathrm{~s}, 3 \mathrm{H}), 2.02(\mathrm{~s}, 3 \mathrm{H})$, 1.90-1.84 (m, 4H). HRMS (ESI $\left.{ }^{+}\right)$: calcd for $[\mathrm{M}+\mathrm{H}]^{+}, 491.17059$; found, 491.17493 .

\section{Synthesis of $\boldsymbol{m}$-methoxycarbonylmethoxytoluene $\left(\mathrm{Bn}\left(\underline{1}^{\mathrm{Me}}\right)\right)$}

A mixture of $m$-cresol (3 g, $27.7 \mathrm{mmol})$, bromomethyl acetate $(4.67 \mathrm{~g}, 30.5 \mathrm{mmol})$, and $\mathrm{Cs}_{2} \mathrm{CO}_{3}(18 \mathrm{~g}, 55.5 \mathrm{mmol})$ in DMF $(100 \mathrm{ml})$ was stirred at room temperature under argon for 4 hours. The inorganic precipitate was filtered off and the filtrate was concentrated under reduced pressure. The residue was diluted with $\mathrm{CH}_{2} \mathrm{Cl}_{2}$ three times, washed with water and saturated aq. $\mathrm{NaCl}$, dried over $\mathrm{Na}_{2} \mathrm{SO}_{4}$, and evaporated. The residue was chromatographed on silica gel with $\mathrm{CH}_{2} \mathrm{Cl}_{2}$ as the eluent to give $\mathbf{B n}\left(\underline{\mathbf{1}}^{\mathrm{Me}}\right)$ as a colorless clear oil (5 g, quant.). ${ }^{1} \mathrm{H}$ $\operatorname{NMR}\left(300 \mathrm{MHz}, \mathrm{CDCl}_{3}\right): \delta 7.17(\mathrm{t}, 1 \mathrm{H}, J=7.9 \mathrm{~Hz}), 6.79-6.84(\mathrm{~m}, 1 \mathrm{H}), 6.73-6.76(\mathrm{~m}, 1 \mathrm{H})$, 6.72-6.68 (m, 1H), $4.62(\mathrm{~s}, 2 \mathrm{H}), 3.79$ (d, $3 \mathrm{H}, J=4.58 \mathrm{~Hz}), 2.33(\mathrm{~s}, 3 \mathrm{H}) ;{ }^{13} \mathrm{C} \mathrm{NMR}(75 \mathrm{MHz}$, $\left.\mathrm{CDCl}_{3}\right): \delta 169.47,157.72,139.64,129.22,122.57,115.49,111.28,65.19,52.14,21.41 ; \mathrm{MS}$ (EI): $m / z, 180\left(\mathbf{M}^{+}\right)$.

\section{Synthesis of $\boldsymbol{m}$-methoxycarbonylmethoxyanisole $\left(\mathrm{Bn}\left(\underline{2}^{\mathrm{Me}}\right)\right)$}

A mixture of $m$-methoxyphenol $(1.72 \mathrm{~g}, 13.8 \mathrm{mmol})$, bromomethyl acetate $(2.34 \mathrm{~g}, 15.2 \mathrm{mmol})$, and $\mathrm{Cs}_{2} \mathrm{CO}_{3}(9 \mathrm{~g}, 27 \mathrm{mmol})$ in DMF (100 ml) was stirred at room temperature under argon for 4 hours. The inorganic precipitate was filtered off and the filtrate was concentrated under reduced pressure. The residue was diluted with $\mathrm{CH}_{2} \mathrm{Cl}_{2}$ three times, washed with water and 
saturated aq. $\mathrm{NaCl}$, dried over $\mathrm{Na}_{2} \mathrm{SO}_{4}$, and evaporated. The residue was chromatographed on silica gel with $\mathrm{CH}_{2} \mathrm{Cl}_{2}$ as the eluent to give $\mathbf{B n}\left(\underline{\mathbf{2}}^{\mathrm{Me}}\right)$ as a colorless clear oil $(2.66 \mathrm{~g}, 98 \%) .{ }^{1} \mathrm{H}$ NMR (300 MHz, CDCl 3 ): $\delta 7.18(\mathrm{t}, 1 \mathrm{H}, J=8.1 \mathrm{~Hz}), 6.57-6.53(\mathrm{~m}, 1 \mathrm{H}), 6.50-6.45(\mathrm{~m}, 2 \mathrm{H})$, $4.61(\mathrm{~s}, 2 \mathrm{H}), 3.80(\mathrm{~s}, 3 \mathrm{H}), 3.78$ (s, 3H).; ${ }^{13} \mathrm{C} \mathrm{NMR}\left(75 \mathrm{MHz}, \mathrm{CDCl}_{3}\right): \delta 169.29,160.83,158.92$, 129.95, 107.45, 106.30, 101.30, 65.24, 55.24, 52.19; MS (EI): $\mathrm{m} / z .196\left(\mathrm{M}^{+}\right)$.

\section{Synthesis of $\boldsymbol{m}$-methoxycarbonylbutyloxytoluene $\left(\mathrm{Bn}\left(\underline{3}^{\mathrm{Me}}\right)\right)$}

A mixture of $m$-cresol ( $1 \mathrm{~g}, 9.2 \mathrm{mmol}), 5$-bromovaleric acid methyl ester $(1.98 \mathrm{~g}, 10.1 \mathrm{mmol})$, and $\mathrm{Cs}_{2} \mathrm{CO}_{3}(6 \mathrm{~g}, 18.5 \mathrm{mmol})$ in DMF $(50 \mathrm{ml})$ was stirred at room temperature under argon for 4 hours. The inorganic precipitate was filtered off and the filtrate was concentrated under reduced pressure. The residue was diluted with $\mathrm{CH}_{2} \mathrm{Cl}_{2}$ three times, washed with water and saturated aq. $\mathrm{NaCl}$, dried over $\mathrm{Na}_{2} \mathrm{SO}_{4}$, and evaporated. The residue was chromatographed on silica gel with $\mathrm{CH}_{2} \mathrm{Cl}_{2}$ as the eluent to give $\mathbf{B n}\left(\underline{3}^{\mathrm{Me}}\right)$ as a colorless clear oil $(2 \mathrm{~g}, 99 \%) .{ }^{1} \mathrm{H}$ NMR (300 MHz, CDCl 3 ): $\delta 7.16(\mathrm{t}, 1 \mathrm{H}, J=7.7 \mathrm{~Hz}), 6.74-6.78(\mathrm{~m}, 1 \mathrm{H}), 6.68-6.74(\mathrm{~m}, 2 \mathrm{H})$, $3.96(\mathrm{t}, 2 \mathrm{H}, J=5.9 \mathrm{~Hz}), 3.68(\mathrm{~s}, 3 \mathrm{H}), 2.41(\mathrm{t}, 2 \mathrm{H}, J=7.0 \mathrm{~Hz}), 2.33(\mathrm{~s}, 3 \mathrm{H}), 1.86-1.80(\mathrm{~m}$, $4 \mathrm{H}) ;{ }^{13} \mathrm{CNMR}\left(75 \mathrm{MHz}, \mathrm{CDCl}_{3}\right): 173.82,158.89,139.34,129.08,121.36,115.27,111.24$, 67.08, 51.43, 33.61, 28.65, 21.60, 21.43; MS (EI): $\mathrm{m} / z 222\left(\mathrm{M}^{+}\right)$.

\section{Supplementary Material}

Refer to Web version on PubMed Central for supplementary material.

\section{Acknowledgements}

This study was supported in part by the Intramural Research Program of the NIH, National Cancer Institute, Center for Cancer Research, a Grant-in-Aid for Creative Scientific Research (No. 13NP0401) to Y. U., research grants (Grant Nos. 13557209, 16651106, and 16689002) to Y. U. and a grant for the Advanced and Innovational Research Program in Life Sciences to T. N., research grants (grant Nos. 16370071 and 16659003) to T. N. from the Ministry of Education, Culture, Sports, Science and Technology of the Japanese Government, and by grants from Hoansha Foundation to T. N. and from Kowa Life Science Foundation to Y. U.

\section{References}

1. Konijn AM, Levy R, Link G, Hershko CJ. Immunol Methods 1982;54:297-307.

2. Armenta R, Tarnowski T, Gibbons I, Ullman EF. Anal Biochem 1985;146:211-219. [PubMed: 3922243]

3. Baruch D, Glickstein H, Cabantchik ZI. Exp Parasitol 1991;73:440-450. [PubMed: 1959571]

4. Fields S, Song OK. Nature 1989;340:245-246. [PubMed: 2547163]

5. Vidal M, Brachmann RK, Fattaey A, Harlow E, Boeke JD. Proc Natl Acad Sci U S A 1996a;93:1031510320. [PubMed: 8816797]

6. Fields S, Sternglanz R. Trends Genet 1994;10:286-292. [PubMed: 7940758]

7. Hamid ME, Chun J, Magee JG, Minnikin DE, Goodfellow M. Zentralbl Bakteriol 1994;280:476-87. [PubMed: 8061408]

8. Nolan GP, Fiering S, Nicolas JF, Herzenberg LA. Proc Natl Acad Sci USA 1988;85:2603-2607. [PubMed: 3128790]

9. Fiering S, Roederer M, Nolan GP, Micklem DR, Parks DR, Herzenberg LA. Cytometry 1991;12:291301. [PubMed: 1905992]

10. Berger CN, Tan S-S, Sturm KS. Cytometry 1994;17:216-223. [PubMed: 7851157]

11. Lin S, Yang S, Hopkins N. Dev Biol 1994;161:77-83. [PubMed: 8293887]

12. Sanes JR, Rubenstein JL, Nicolas JF. EMBO J 1986;5:3133-3142. [PubMed: 3102226]

13. James AL, Perry JD, Chilvers K, Robson IS, Armstrong L, Orr KE. Lett Appl Microbiol 2000;30:336340. [PubMed: 10792658]

14. Rotman B, Zderic JA, Edelstein M. Proc Natl Acad Sci U S A 1963;50:1-6. [PubMed: 13975398] 
15. Rakhmanova VA, MacDonald RC. Anal Biochem 1998;257:234-237. [PubMed: 9514778]

16. Young DC, Kingsley SD, Ryan KA, Dutko FJ. Anal Biochem 1993;215:24-30. [PubMed: 8297011]

17. Chilvers KF, Perry JD, James AL, Reed RH. J Appl Microbiol 2001;91:1118-1130. [PubMed: 11851821]

18. Gee KR, Sun WC, Bhalgat MK, Upson RH, Klaubert DH, Latham KA, Haugland RP. Anal Biochem 1999;273:41-48. [PubMed: 10452797]

19. Corey PF, Trimmer RW, Biddlecom WG. Angew Chem Int Ed Engl 1991;30:1646-1648.

20. Takayasu S, Maeda M, Tsuji A. J Immunol Methods 1985;83:317-325. [PubMed: 2414365]

21. Arakawa H, Maeda M, Tsuji A. Anal Biochem 1991;199:238-42. [PubMed: 1725950]

22. Alauddin MM, Louie AY, Shahinian A, Meade TJ, Conti PS. Nuclear Medicine and Biology 2003;30:261-265. [PubMed: 12745017]

23. Tung C-H, Zeng Q, Shah K, Kim DE, Schellingerhout D, Weissleder R. Cancer Research 2004;64:1579-1583. [PubMed: 14996712]

24. Louie AY, Hüber MM, Ahrens ET, Rothbächer U, Moats R, Jacobs RE, Fraser SE, Meade TJ. Nat Biotechnol 2000;18:321-325. [PubMed: 10700150]

25. Wehrman TS, Degenfeld Gv, Krutzik PO, Nolan GP, Blau HM. Nat Methods 2006;3:295-301. [PubMed: 16554835]

26. Urano Y, Kamiya M, Kanda K, Ueno T, Hirose K, Nagano T. J Am Chem Soc 2005;127:4888-4894. [PubMed: 15796553]

27. Takeda A, Manabe S, Mitsui T, Nakamura H. Gynecol Surg 2006;3:45-48.

28. Kim S, Lim YT, Soltesz EG, De Grand AM, Lee J, Nakayama A, Parker JA, Mihaljevic T, Laurence RG, Dor DM, Cohn LH, Bawendi MG, Frangioni JV. Nat Biotechnol 2004;22:93-97. [PubMed: 14661026]

29. Minta A, Kao JPY, Tsien RY. J Boil Chem 1989;264:8171-8178.

30. Zlokarnik G, Negulescu PA, Knapp TE, Mere L, Burres N, Feng L, Whitney M, Roemer K, Tsien RY. Science 1998;279:84-88. [PubMed: 9417030]

31. Tanaka K, Miura T, Umezawa N, Urano Y, Kikuchi K, Higuchi T, Nagano T. J Am Chem Soc 2001;123:2530-2536. [PubMed: 11456921]

32. Miura T, Urano Y, Tanaka K, Nagano T, Ohkubo K, Fukuzumi S. J Am Chem Soc 2003;125:86668671. [PubMed: 12848574]

33. Senter PD, Saulnier MG, Schreiber GJ, Hirschberg DL, Brown JP, Hellström I, Hellström KE. Proc Nati Acad Sci USA 1988;85:4842-4846.

34. Senter PD, Springer CJ. Advanced drug delivery reviews 2001;53:247-264. [PubMed: 11744170]

35. Hama Y, Urano Y, Koyama Y, Kamiya M, Bernardo M, Paik RS, Krishna MC, Choyke PL, Kobayashi H. Neoplasia 2006;8:607-612. [PubMed: 16867223]

36. Yao Z, Zhang M, Sakahara H, Saga T, Arano Y, Konishi J. J Natl Cancer Inst 1998;90:25-29. [PubMed: 9428779]

37. Mamede M, Saga T, Kobayashi H, Ishimori T, Higashi T, Sato N, Brechbiel MW, Konishi J. Clinical Cancer Research 2003;9:3756-3762. [PubMed: 14506168]

38. Sato N, Kobayashi H, Saga T, Nakamoto Y, Ishimori T, Togashi K, Fujibayashi Y, Konishi J,

Brechbiel MW. Clinical Cancer Research 2001;7:3606-3612. [PubMed: 11705883]

39. Paeker CA, Rees WT. Analyst 1960;85:587-600. 


\section{(a)}
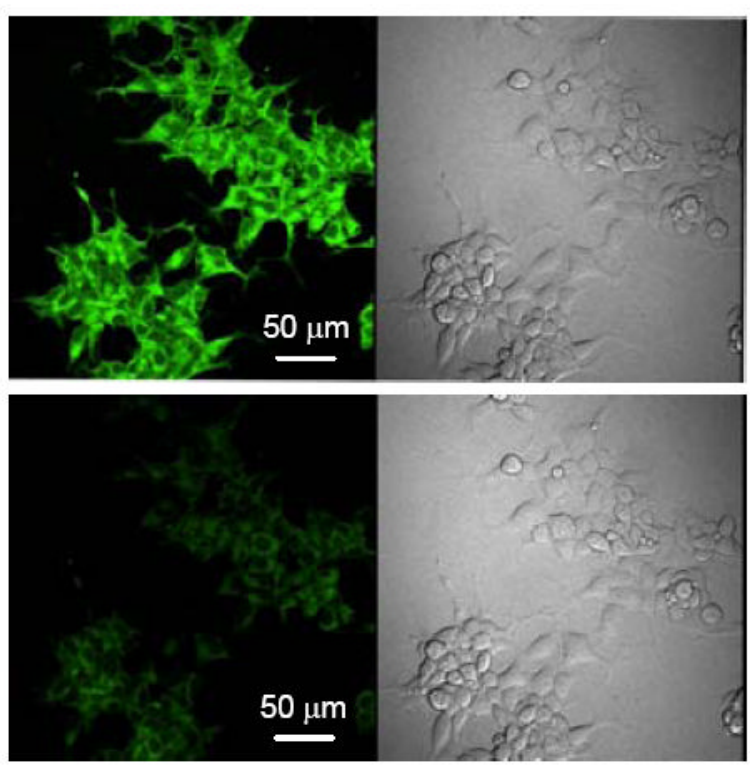

(b)
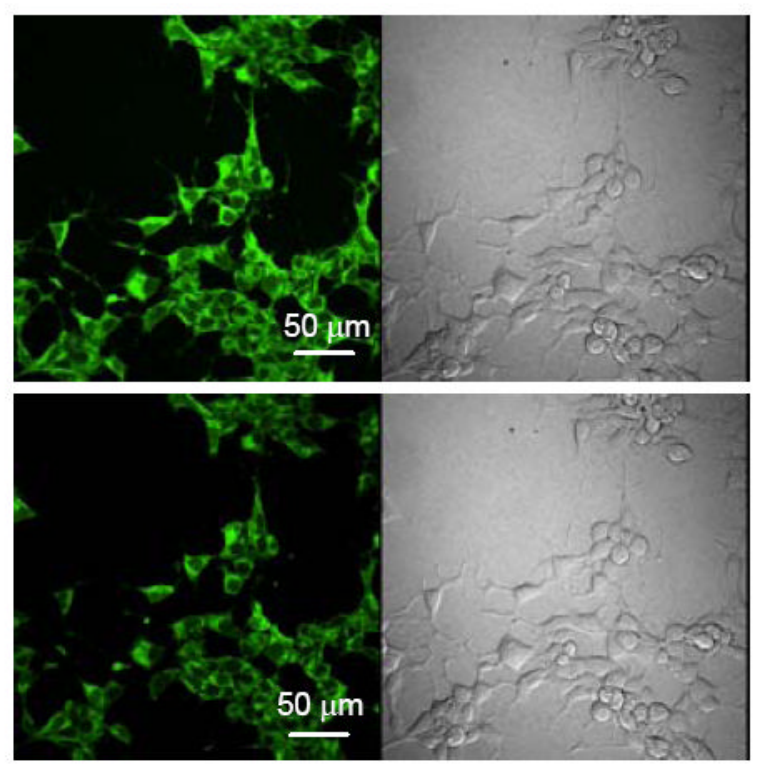

Figure 1.

Fluorescence microscopic imaging of $\beta$-galactosidase activity in living cells with TG- $\beta \mathrm{Gal}$ and

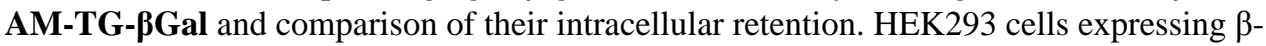
galactosidase were incubated with a $10 \mu \mathrm{M}$ solution of TG- $\beta \mathrm{Gal}$ (a) or AM-TG- $\boldsymbol{\beta}$ Gal (b) in physiological salt solution, $\mathrm{pH} 7.4$, containing $150 \mathrm{mM} \mathrm{NaCl}, 4 \mathrm{mM} \mathrm{KCl}, 2 \mathrm{mM} \mathrm{CaCl}_{2}, 1 \mathrm{mM}$ $\mathrm{MgCl}_{2}, 5 \mathrm{mM}$ HEPES, and $0.1 \%$ glucose (PSS), and $0.1 \%$ DMSO as a cosolvent for 2 hours. Then, confocal fluorescence images and DIC images were captured before (Upper) and after (Lower) washing with PSS. A clear decrease of fluorescence was observed in the case of cells incubated with TG- $\beta \mathrm{Gal}$, while little change was observed in the case of cells incubated with AM-TG-BGal. 


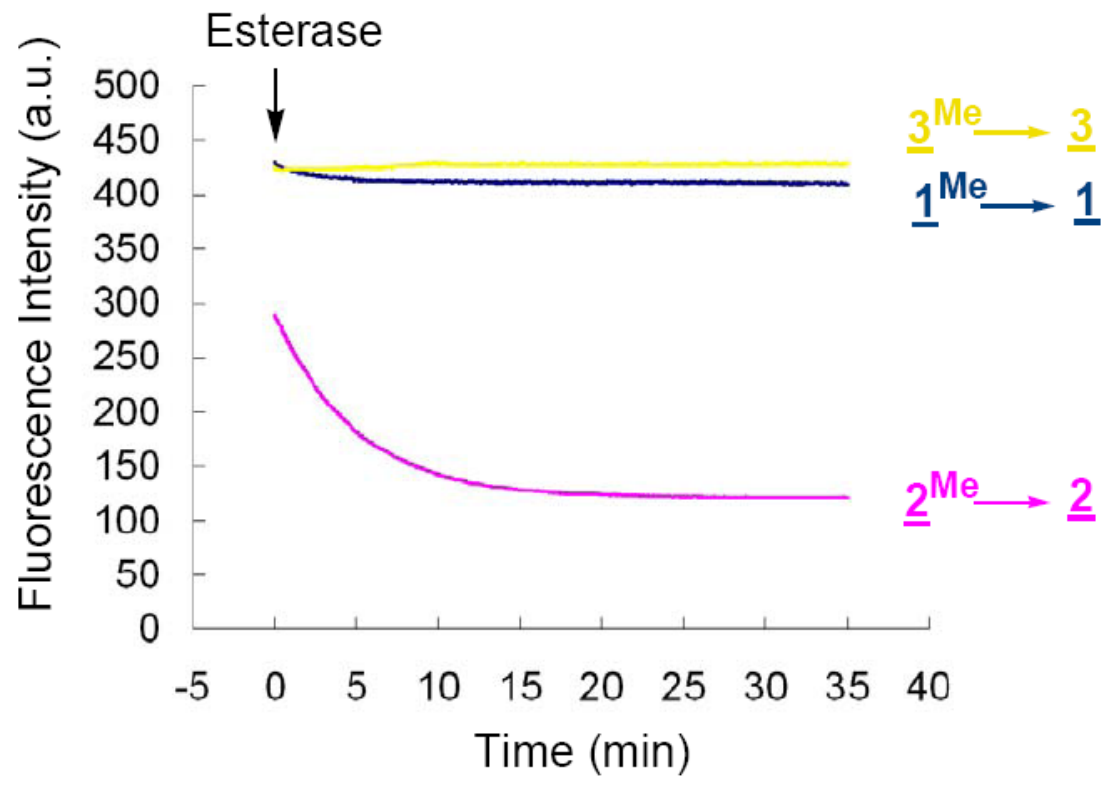

Figure 2.

Fluorescence change of $\underline{\mathbf{1}}^{\mathbf{M e}}, \underline{\mathbf{2}}^{\mathbf{M e}}, \underline{\mathbf{3}}^{\mathbf{M e}}$ upon reaction with esterase. Porcine liver esterase (10 units) was added at 0 minute to solutions of $\underline{\mathbf{1}}^{\mathbf{M e}}, \underline{\mathbf{2}}^{\mathbf{M e}}$, and $\underline{\mathbf{3}}^{\mathbf{M e}}$ in $100 \mathrm{mM}$ sodium phosphate buffer, $\mathrm{pH} 7.4$, containing 0.1\% DMSO as a cosolvent. Excitation and emission wavelengths were $491 \mathrm{~nm}$ and $510 \mathrm{~nm}$, respectively. 


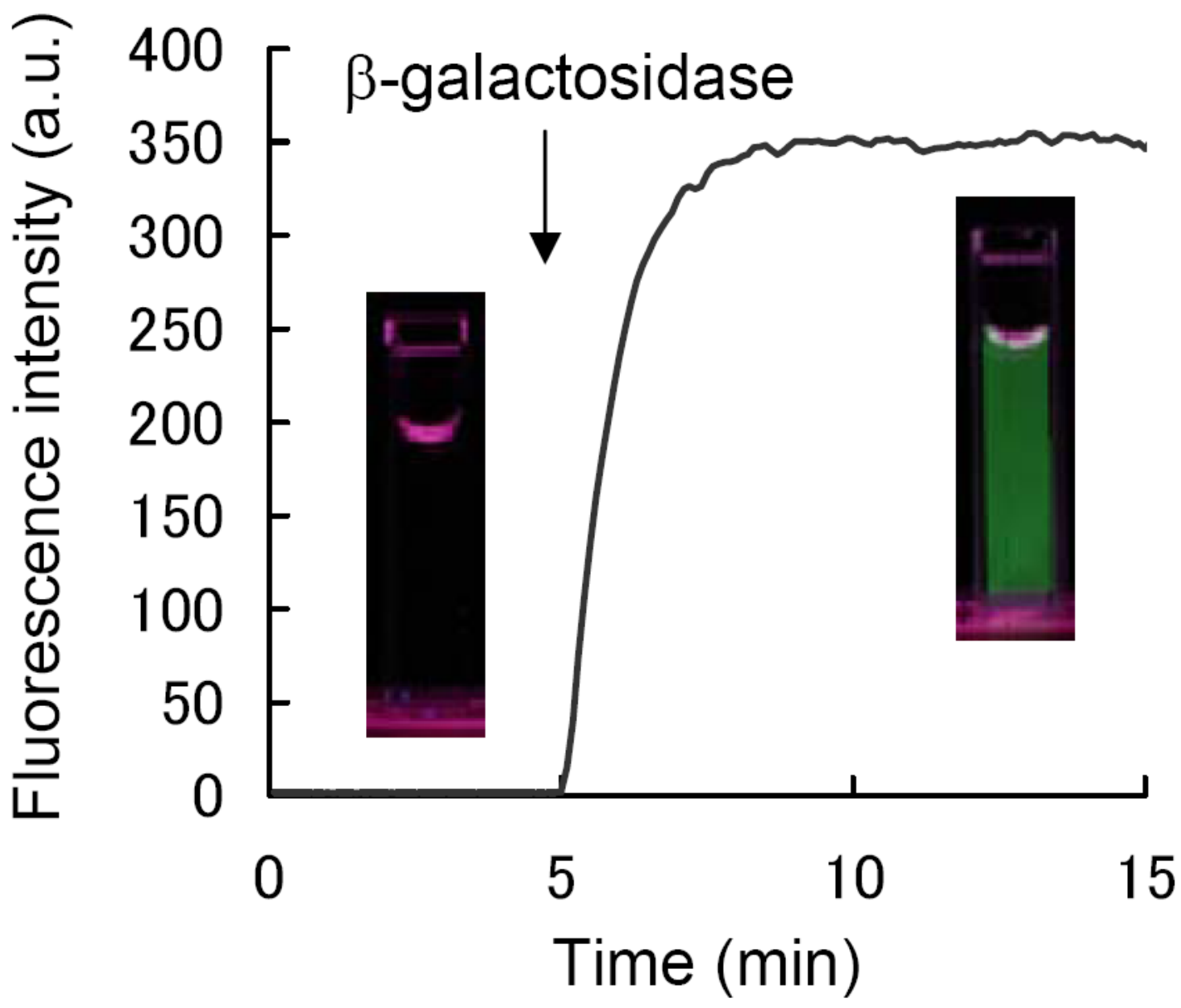

Figure 3.

In vitro reaction of AM-TG- $\beta$ Gal with $\beta$-galactosidase. The fluorescence increase of $1 \mu \mathrm{M}$ AM-TG-BGal in $100 \mathrm{mM}$ sodium phosphate buffer, $\mathrm{pH} 7.4$, containing $1 \mathrm{mM} \mathrm{MgCl} 2,14.3$ $\mathrm{mM} 2$-mercaptoethanol, $0.1 \% \mathrm{DMSO}$, and $6 \mathrm{U}$ of $\beta$-galactosidase at $37^{\circ} \mathrm{C}$ is shown. Excitation and emission wavelengths were $492 \mathrm{~nm}$ and $509 \mathrm{~nm}$, respectively. 

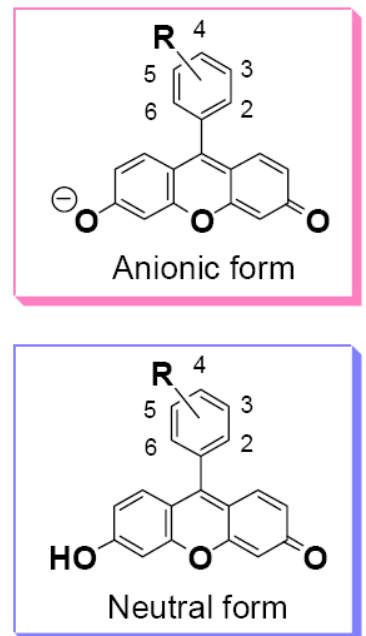

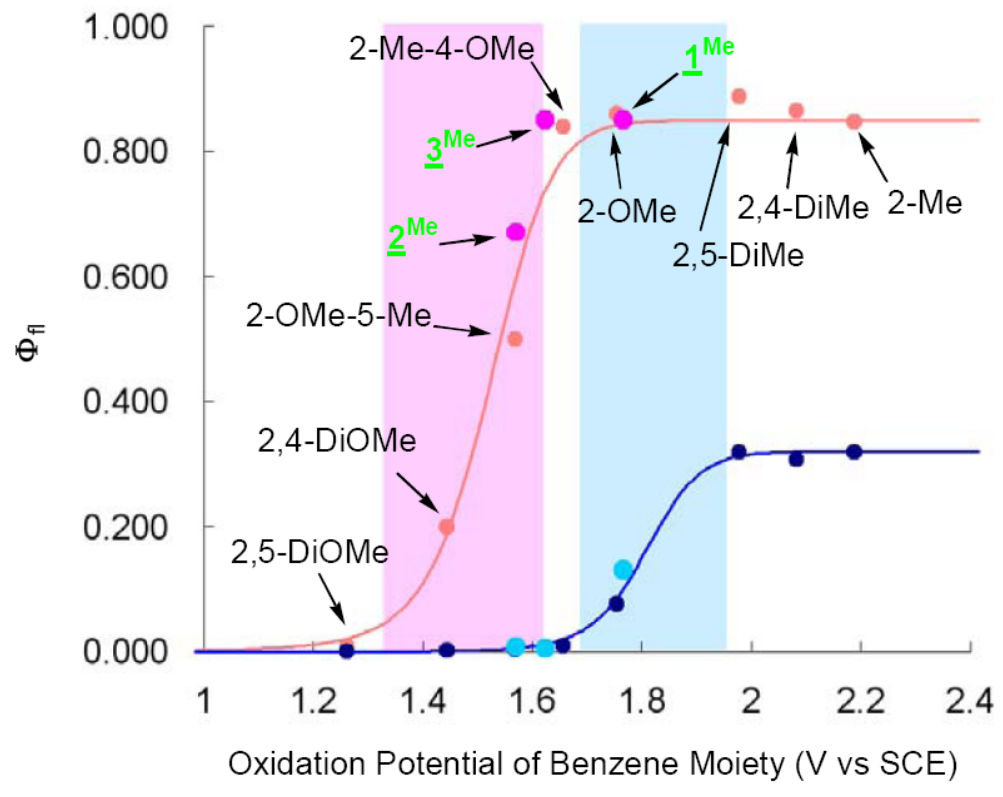

Figure 4.

Relationship between the oxidation potential of the benzene moiety and $\Phi_{\mathrm{fl}}$ of the anion form (red) and neutral form (blue). Data for previously reported TokyoGreen derivatives ${ }^{26}$ and the newly developed $\underline{\mathbf{1}}^{\mathrm{Me}}, \underline{\mathbf{2}}^{\mathrm{Me}}$, and $\underline{\mathbf{3}}^{\mathrm{Me}}$ are depicted on the same graph. The curve represents the best fit to the Marcus equation. 


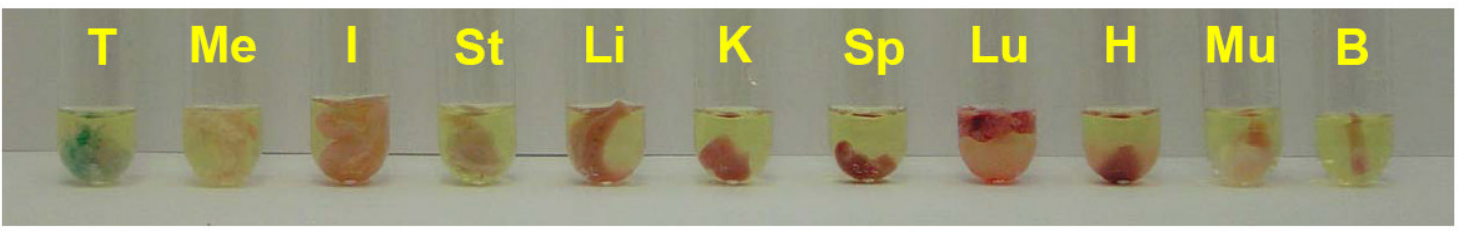

Figure 5.

In vivo targeting of avidin- $\beta$-galactosidase to intraperitoneal SHIN3 tumors in mouse. Avidin$\beta$-galactosidase (100 $\mu \mathrm{g})$ in PBS(-) was injected intraperitoneally into a SHIN3-implanted mouse, and after 20 hours the mouse was sacrificed. The main internal organs (tumor (T), mesentery (Me), intestine (I), stomach (St), liver (Li), kidney (K), spleen (Sp), lung (Lu), heart $(\mathrm{H})$, muscle $(\mathrm{Mu})$, bone $(\mathrm{B}))$ were removed and stained with $\mathrm{X}-\mathrm{Gal}$ for 2 hours. 
(a)

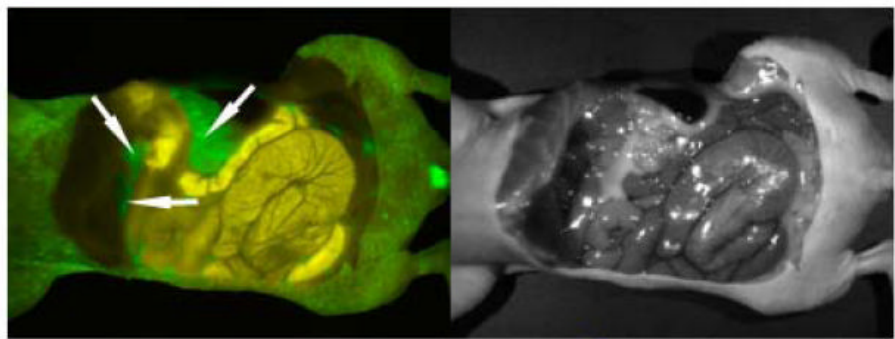

(b)

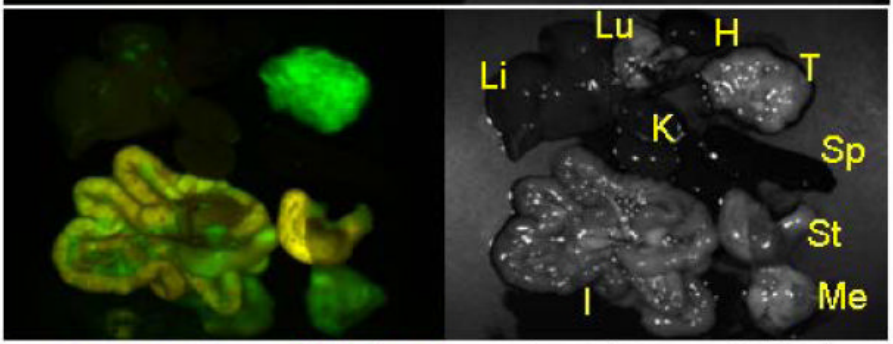

(c)

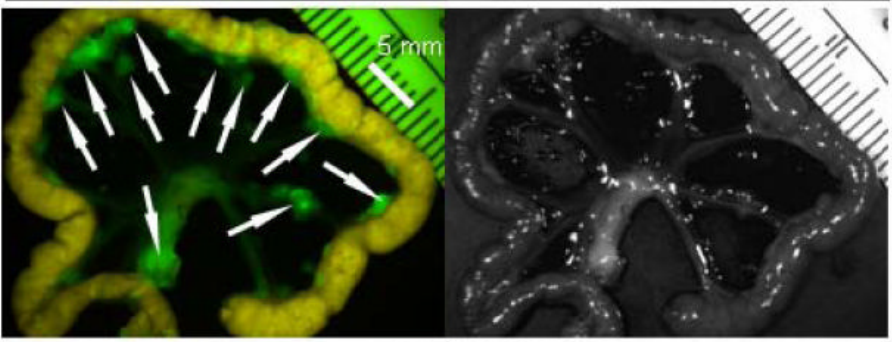

(d)

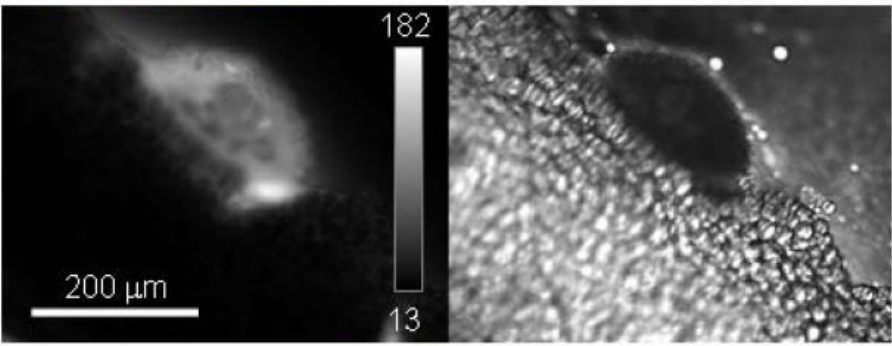

(e)

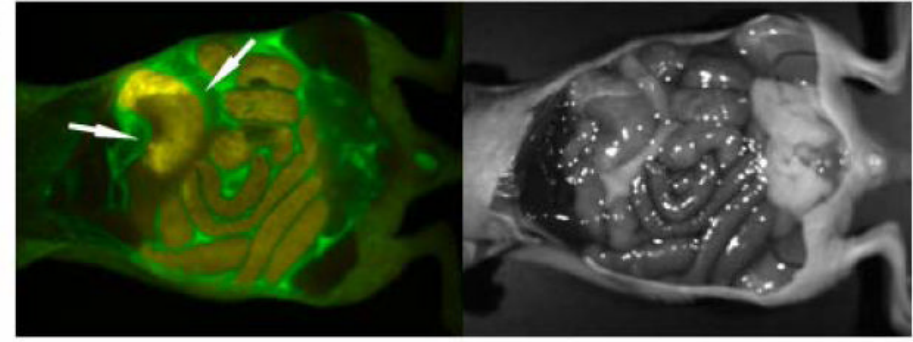

Figure 6.

Ex vivo fluorescence imaging of SHIN3-targeted $\beta$-galactosidase activity with AM-TG-

$\boldsymbol{\beta G a l}$ or TG- $\beta$ Gal. (a) Tumors were imaged with AM-TG-קGal, following pretreatment with avidin- $\beta$-galactosidase. Tumors (Arrows) were clearly visualized with a high tumor-tonontumor signal ratio. (b) Ex vivo fluorescence imaging of the main internal organs of the mouse. T; tumor, Me; mesentery, I; intestine, St; stomach, Li; liver, K; kidney, Sp; spleen, Lu; lung, H; heart. (c) Magnified image of a peritoneal tumor. Strong fluorescence signals reveal tiny peritoneal tumor nodules (Arrows). (d) Fluorescent microfoci as small as $200 \mu \mathrm{m}$ in diameter can be seen by using fluorescence microscopy. (e) Tumor imaging with TG- $\beta \mathrm{Gal}$, following pretreatment with avidin- $\beta$-galactosidase. Strong fluorescence was observed in the 
peritoneal cavity, however, this was unlikely to have been confined to tumors, owing to the rapid leakage of its fluorescent product. The unmixed fluorescence images (Left) and white light images (Right) of (a), (b), (c) and (e) were captured with a Maestro ${ }^{\mathrm{TM}}$ In-Vivo Imaging System (CRI Inc., Woburn, MA, USA). To obtain the unmixed fluorescence images, spectral division was performed using the autofluorescence of intestine (Yellow) and the fluorescence at the tumor (Green). The fluorescence image (Left) and DIC image (Right) of (d) were captured with a BX51 microscope (Olympus USA, Melville, NY). 


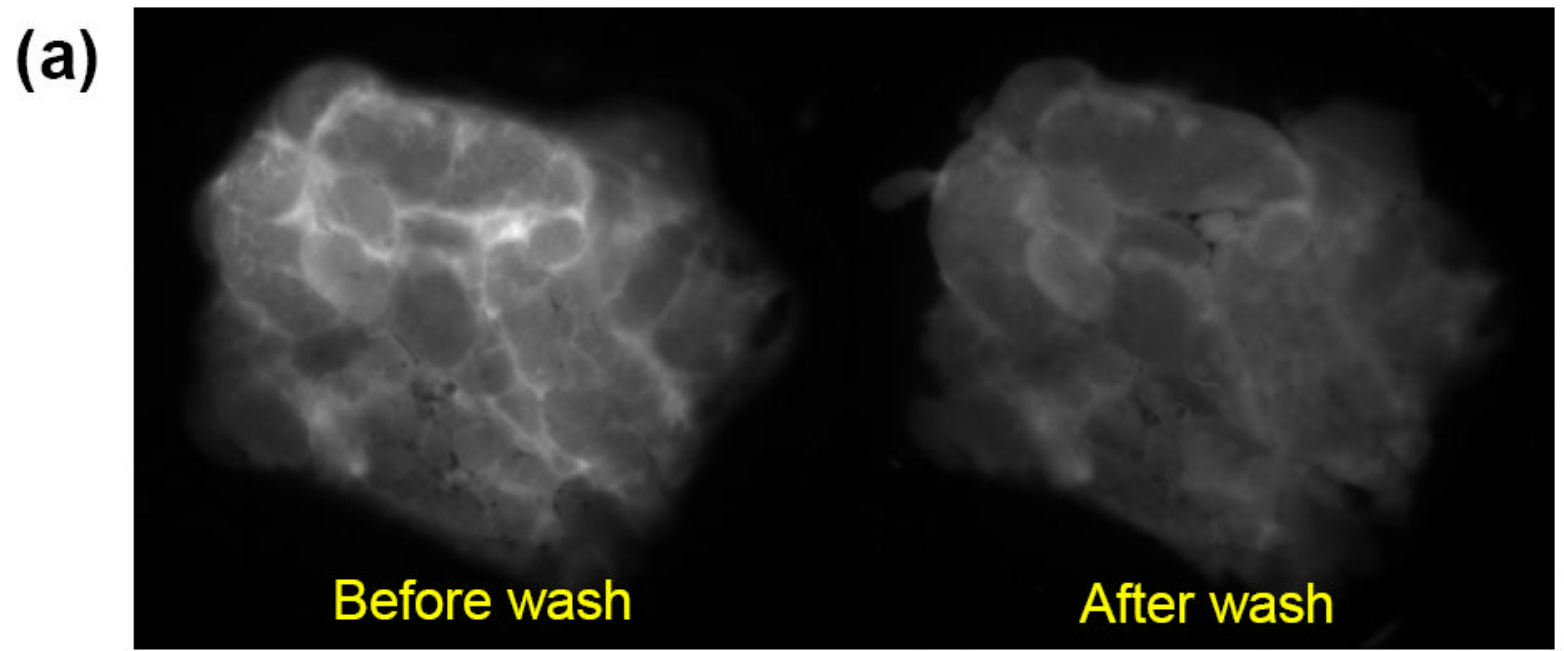

\section{(b)}

\section{Before wash}

\section{After wash}

Figure 7.

Fluorescence images of SHIN3 tumors removed from a mouse after incubation with TG- $\beta$ Gal (a) or AM-TG-ßGal (b), before and after washing with PBS. 


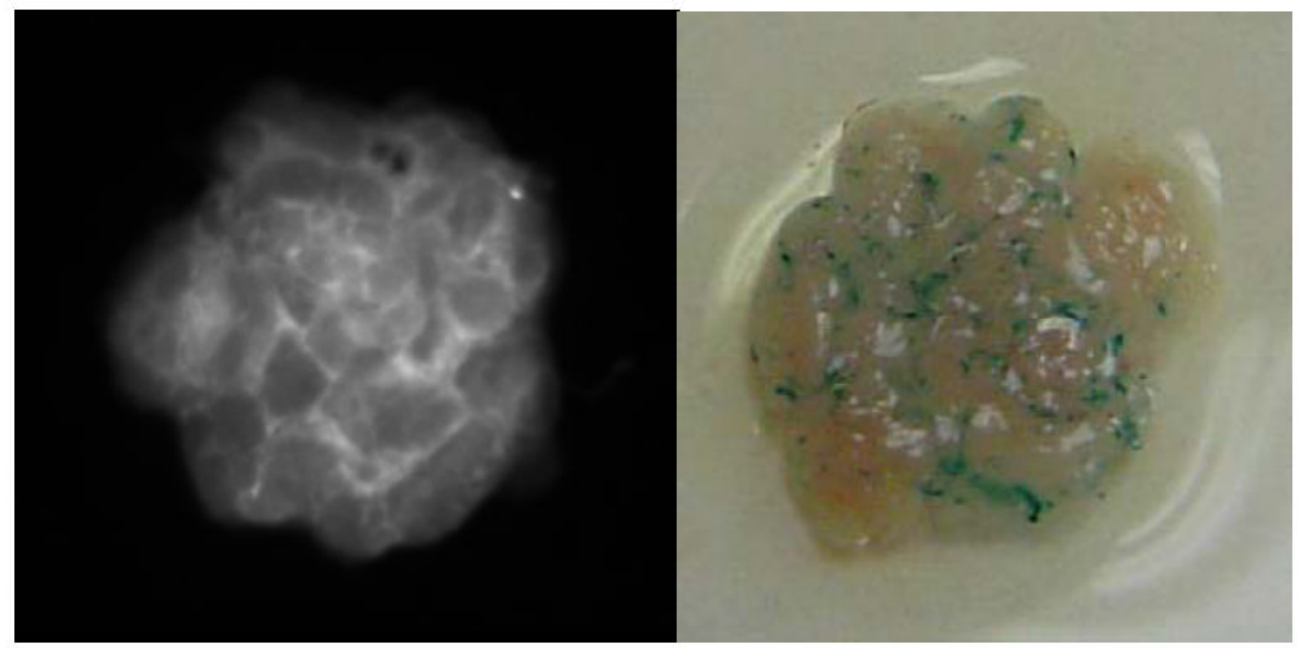

Figure 8.

Distribution of $\beta$-galactosidase activity in the removed tumor. Avidin- $\beta$-galactosidase was intraperitoneally injected into SHIN3-implanted mouse, then AM-TG-קGal was administered. The tumor was removed and stained with X-Gal for 1 hour. 
(a)

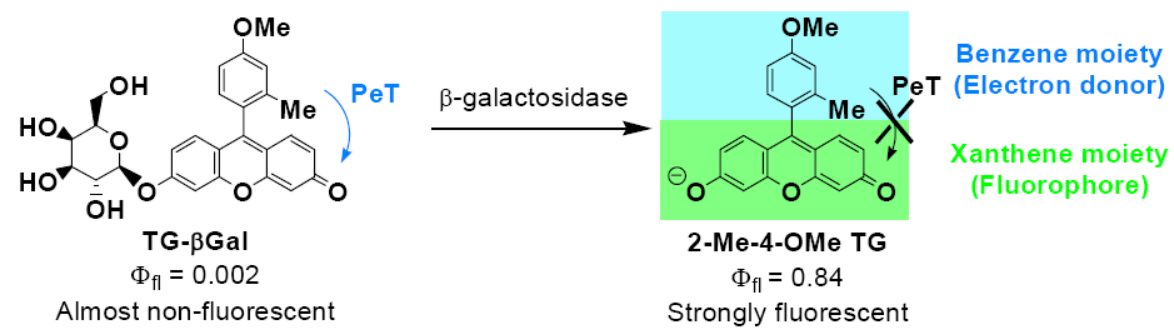

(b)

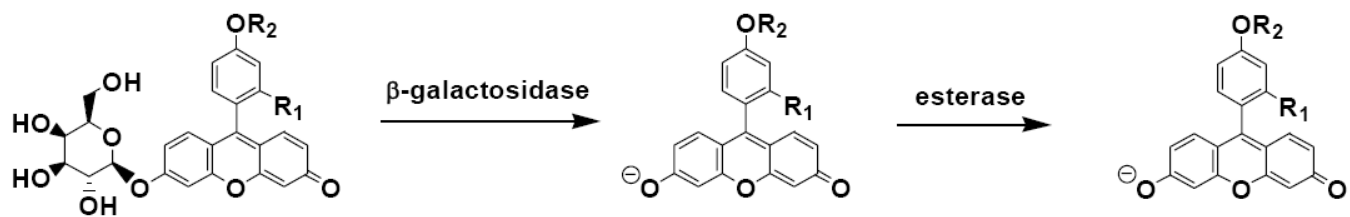

$\mathbf{R}_{1}=\mathrm{Me}, \mathrm{R}_{2}=\mathrm{CH}_{2} \mathrm{COOMe}: 1^{\mathrm{Me}}-\beta \mathrm{Gal}$

$\mathbf{R}_{\mathbf{1}}=\mathrm{Me}, \mathbf{R}_{\mathbf{2}}=\mathrm{CH}_{2} \mathrm{COOMe}: 1^{\mathrm{Me}}$

$\mathbf{R}_{1}=\mathrm{OMe}, \mathbf{R}_{2}=\mathrm{CH}_{2} \mathrm{COOMe}: \underline{\mathbf{2}}^{\mathrm{Me}}-\beta \mathrm{Gal}$
$\mathbf{R}_{1}=\mathrm{Me}, \mathbf{R}_{\mathbf{2}}=\left(\mathrm{CH}_{2}\right)_{4} \mathrm{COOMe}: \underline{3}^{\mathrm{Me}}-\beta \mathrm{Gal}$

$\mathbf{R}_{\mathbf{1}}=\mathrm{OMe}, \mathbf{R}_{\mathbf{2}}=\mathrm{CH}_{2} \mathrm{COOMe}: \underline{\mathbf{2}}^{\mathrm{Me}}$

$\mathbf{R}_{\mathbf{1}}=\mathrm{Me}, \mathbf{R}_{\mathbf{2}}=\mathrm{CH}_{2} \mathrm{COOH} \quad: \underline{1}$

$\mathbf{R}_{1}=\mathrm{Me}, \mathbf{R}_{\mathbf{2}}=\left(\mathrm{CH}_{2}\right)_{4} \mathrm{COOMe:} \underline{3}^{\mathrm{Me}}$

$\mathbf{R}_{\mathbf{1}}=\mathrm{OMe}, \mathbf{R}_{\mathbf{2}}=\mathrm{CH}_{2} \mathrm{COOH}: 2$

$\mathbf{R}_{\mathbf{1}}=\mathrm{Me}, \mathbf{R}_{\mathbf{2}}=\left(\mathrm{CH}_{2}\right)_{4} \mathrm{COOH}: \underline{3}$

(c)

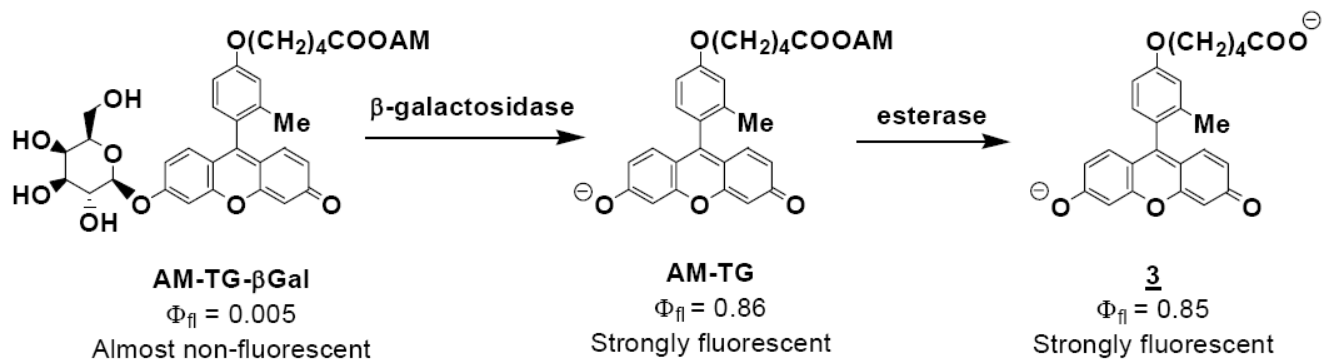

Scheme 1.

Reaction schemes of our fluorescence probes with $\beta$-galactosidase and intracellular esterase.

(a) Reaction of our previously reported $\beta$-galactosidase probe, TG- $\beta$ Gal, with $\beta$-galactosidase. (b) Newly developed $\beta$-galactosidase substrates bearing an esterase-sensitive methylester, $\underline{\mathbf{1}}^{\mathrm{Me}} \boldsymbol{- \beta G a l}, \underline{2}^{\mathrm{Me}} \boldsymbol{\beta} \boldsymbol{\beta G a l}$, and $\underline{3}^{\mathrm{Me}} \boldsymbol{- \beta G a l}$. (c) Our newly developed fluorescence probe, AM-TG$\boldsymbol{\beta} \mathbf{G a l}$, which shows a large fluorescence increase upon reaction with $\beta$-galactosidase, and is further hydrolyzed by intracellular esterase to the free carboxylate, which is well retained in the cells without loss of fluorescence. 


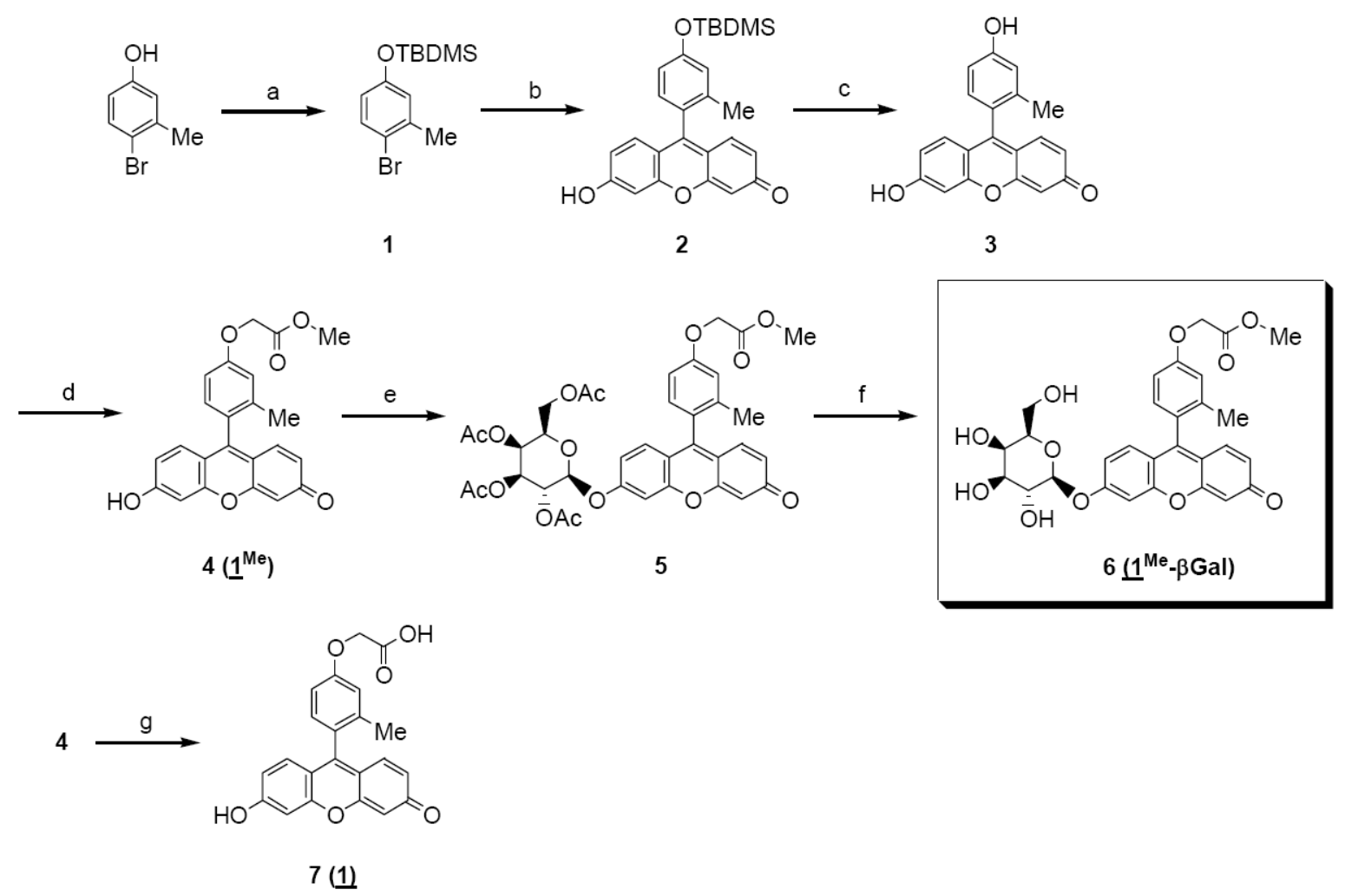

Scheme 2.

Synthetic scheme of $\underline{\mathbf{1}}^{\mathrm{Me}} \boldsymbol{- \beta G a l}$. Reagents. (a) TBDMS-Cl, imidazole, DMF; (b) 3,6-Bis- $(t$ butyldimethylsilanyloxy)xanthen-9-one, $t$-BuLi, THF; (c) TBAF, THF; (d) Methyl bromoacetate, $\mathrm{Cs}_{2} \mathrm{CO}_{3}$, DMF; (e) 2,3,4,6-tetra-O-acetyl- $\alpha$-D-galactopyranosyl bromide, $\mathrm{Cs}_{2} \mathrm{CO}_{3}$, DMF; (f) $\mathrm{NaOMe}, \mathrm{MeOH}$; (g) aq. $\mathrm{NaOH}, \mathrm{MeOH}$. 

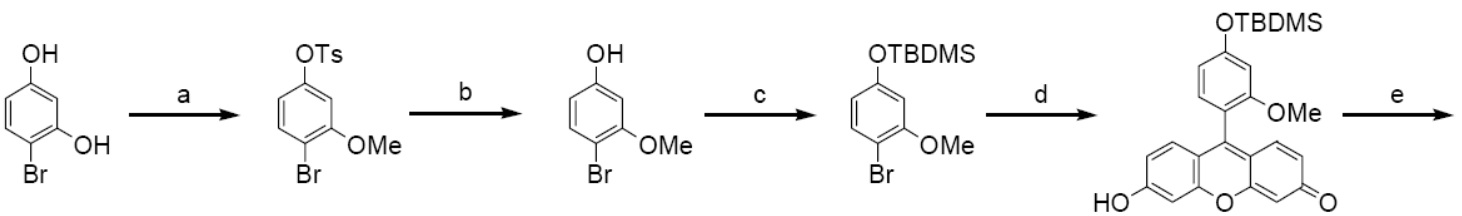

8

9

10

11
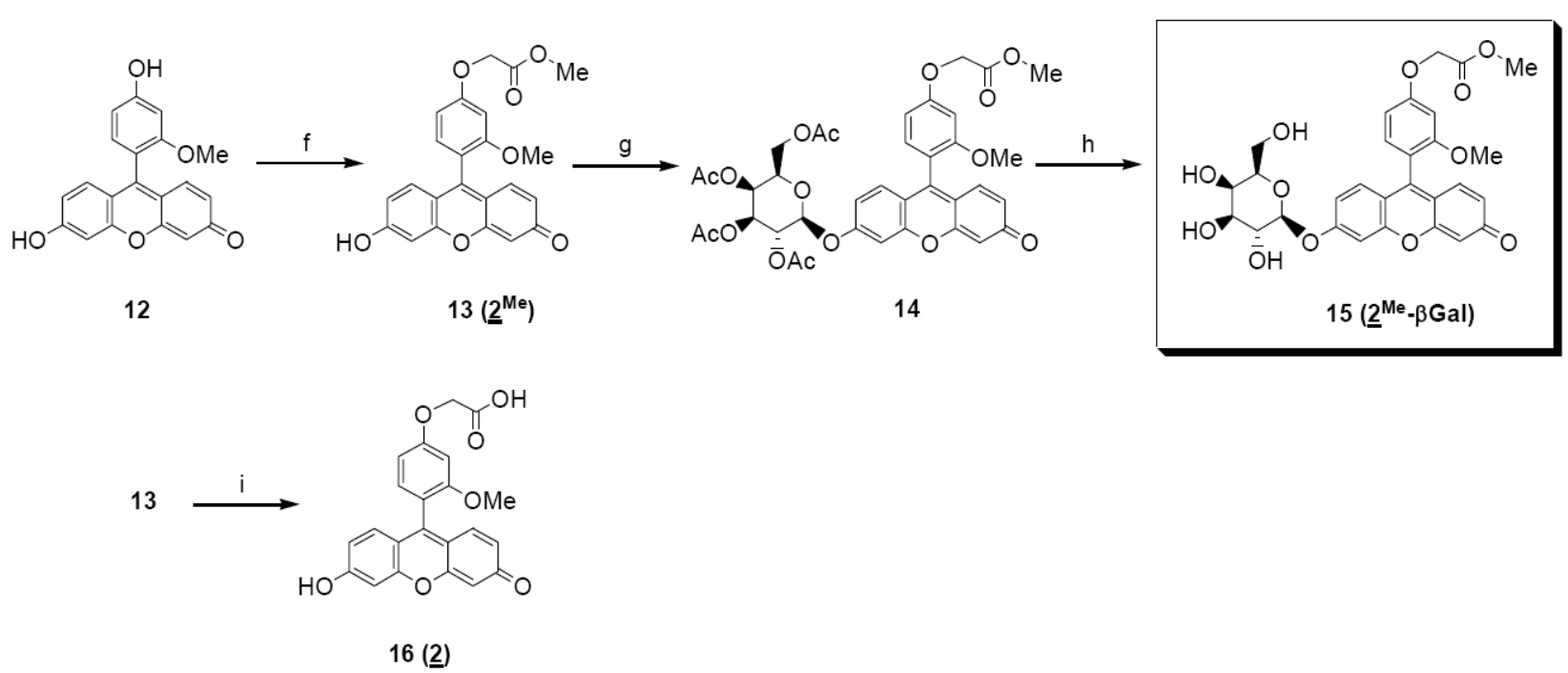

Scheme 3.

Synthetic scheme of $\underline{\mathbf{2}}^{\mathrm{Me}} \boldsymbol{- \beta G a l}$. Reagents. (a) 1) $\mathrm{TsCl}, \mathrm{K}_{2} \mathrm{CO}_{3}$, acetone, 2) MeI; (b) aq.NaOH, $\mathrm{MeOH}$; (c) TBDMS-Cl, imidazole, DMF; (d) 3,6-Bis-( $t$-butyldimethylsilanyloxy)xanthen-9one, $t$-BuLi, THF; (e) TBAF, THF; (f) Methyl bromoacetate, $\mathrm{Cs}_{2} \mathrm{CO}_{3}$, DMF; (g) 2,3,4,6-tetraO-acetyl- $\alpha$-D-galactopyranosyl bromide, $\mathrm{Cs}_{2} \mathrm{CO}_{3}$, DMF; (h) $\mathrm{NaOMe}, \mathrm{MeOH}$; (i) aq.NaOH, $\mathrm{MeOH}$. 


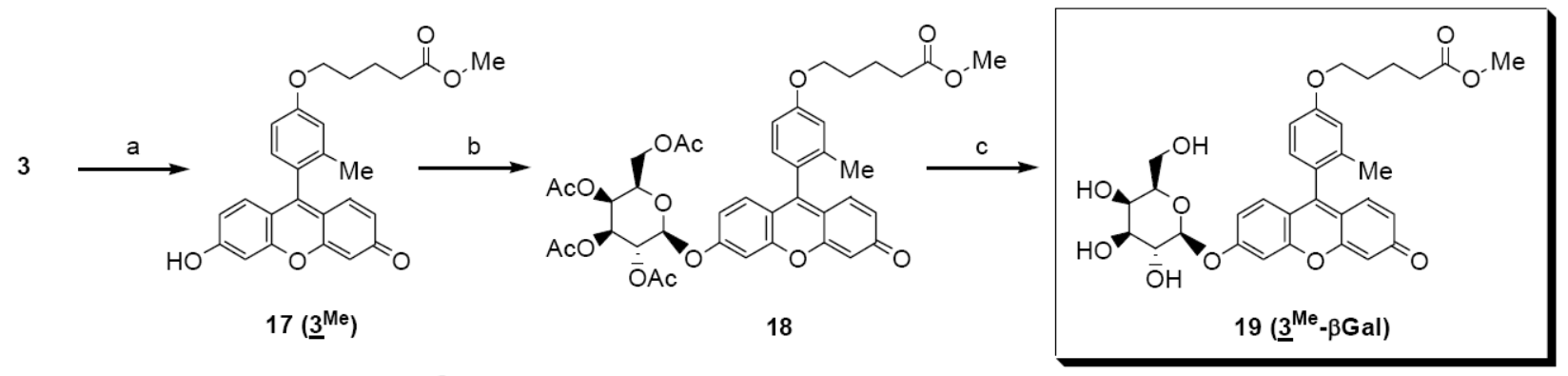<smiles></smiles>

Scheme 4.

Synthetic scheme of $\underline{\mathbf{3}}^{\mathrm{Me}}$ - $\boldsymbol{\beta G G a l}$. Reagents. (a) Methyl bromovalerate, $\mathrm{Cs}_{2} \mathrm{CO}_{3}$, DMF; (b) 2,3,4,6-tetra-O-acetyl- $\alpha$-D-galactopyranosyl bromide, $\mathrm{Cs}_{2} \mathrm{CO}_{3}$, DMF; (c) $\mathrm{NaOMe}, \mathrm{MeOH}$; (d) aq. $\mathrm{NaOH}, \mathrm{MeOH}$. 


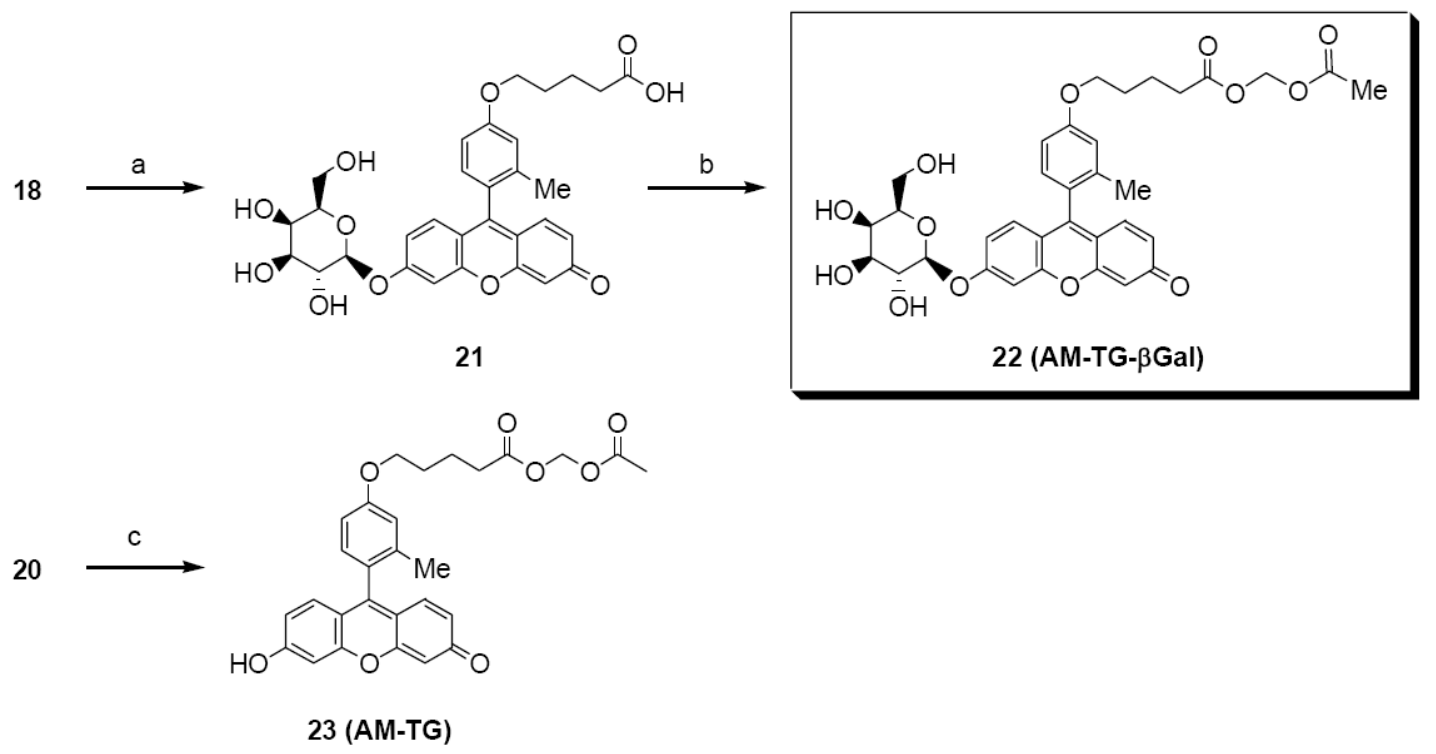

Scheme 5.

Synthetic scheme of AM-TG-קGal. Reagents. (a) aq. $\mathrm{NaOH}, \mathrm{MeOH} / \mathrm{H}_{2} \mathrm{O}$; (b) Bromomethyl acetate, DIEA, MeOH/MeCN; (c) Bromomethyl acetate, DIEA, DMF. 
Table 1

Absorption and fluorescence properties of the newly developed $\beta$-galactosidase substrates and their esterase and/or $\beta$ galactosidase-catalyzed hydrolysis products.

\begin{tabular}{|c|c|c|c|c|}
\hline Compound & Absorption maximum $(\mathrm{nm})^{a}$ & Emission maximum $(\mathrm{nm})^{a}$ & Fluorescence quantum yield $b$ & Fluorescence enhancement $c$ \\
\hline 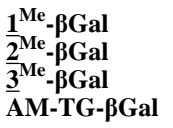 & $\begin{array}{l}454 \\
452 \\
452 \\
453\end{array}$ & $\begin{array}{l}515 \\
527 \\
512 \\
518\end{array}$ & $\begin{array}{l}0.069 \\
0.004 \\
0.009 \\
0.005\end{array}$ & $\begin{array}{c}46 \\
410 \\
370 \\
470\end{array}$ \\
\hline 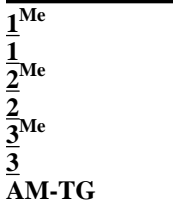 & $\begin{array}{l}492 \\
491 \\
494 \\
494 \\
491 \\
491 \\
491\end{array}$ & $\begin{array}{l}511 \\
510 \\
516 \\
515 \\
510 \\
510 \\
510\end{array}$ & $\begin{array}{l}0.85 \\
0.83 \\
0.67 \\
0.32 \\
0.85 \\
0.85 \\
0.86\end{array}$ & $\begin{array}{l}- \\
- \\
- \\
- \\
- \\
- \\
-\end{array}$ \\
\hline
\end{tabular}

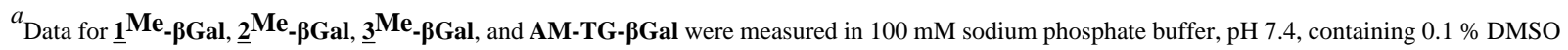
as a cosolvent. Data for $\underline{\mathbf{1}}^{\mathbf{M e}}, \underline{\mathbf{2}}^{\mathbf{M e}}, \underline{\mathbf{3}}^{\mathbf{M e}}, \underline{\mathbf{1}}, \underline{\mathbf{2}}, \underline{\mathbf{3}}$, and AM-TG were measured in $100 \mathrm{mM}$ sodium phosphate buffer, pH 9.0, containing $0.1 \%$ DMSO as a cosolvent.

${ }^{b}$ For determination of the fluorescence quantum yield, fluorescein in $100 \mathrm{mM}$ aq. $\mathrm{NaOH}(0.85)$ was used as a fluorescence standard. 39

${ }^{c}$ Fluorescence enhancement represents the ratio of fluorescence intensity at $509-511 \mathrm{~nm}$ before and after hydrolysis by $\beta$-galactosidase. 


\section{Table 2}

Oxidation potential and calculated HOMO energy level of the benzene moiety of $\underline{\mathbf{1}}^{\mathbf{M e}} \boldsymbol{- \boldsymbol { \beta G a l }}, \underline{\mathbf{2}}^{\mathrm{Me}} \boldsymbol{\boldsymbol { \beta G a l }}$, and $\underline{\mathbf{3}}^{\mathrm{Me}}$. $\boldsymbol{\beta G a l}$. Bn(1 $\left.\underline{\mathbf{M e}}^{\mathrm{Me}}\right) \operatorname{Bn}\left(\underline{\mathbf{2}}^{\mathrm{Me}}\right)$, and $\operatorname{Bn}\left(\underline{3}^{\mathrm{Me}}\right)$ correspond to the benzene moiety of $\underline{\mathbf{1}}^{\mathrm{Me}} \boldsymbol{\beta} \mathbf{\beta a l}, \underline{\mathbf{2}}^{\mathrm{Me}} \boldsymbol{\beta G a l}$, and $\underline{3}^{\mathrm{Me}} \boldsymbol{\beta} \boldsymbol{\beta G a l}$, respectively.

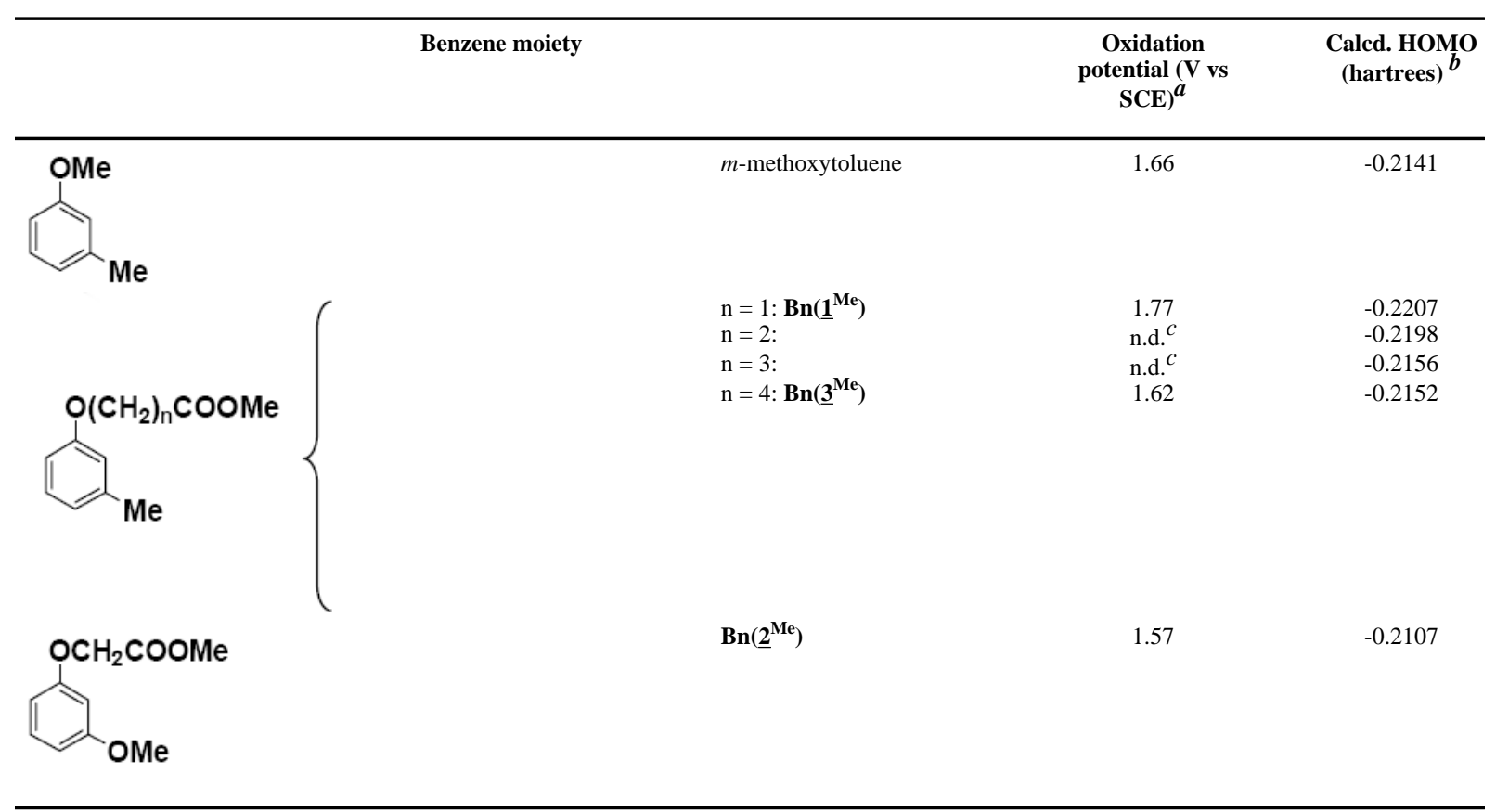

${ }^{a}$ All data were measured in $100 \mathrm{mM}$ TBAF MeCN, with $\mathrm{Ag} / \mathrm{Ag}^{+}$as a reference electrode.

${ }^{b}$ HOMO level was calculated at the B3LYP/6-31G level.

${ }^{c}$ n.d.; not determined. 
Table 3

Fluorescence quantum yields of anionic and neutral forms of $\underline{\mathbf{1}}^{\mathrm{Me}}, \underline{\mathbf{2}}^{\mathrm{Me}}, \underline{\mathbf{3}}^{\mathrm{Me}}$.

\begin{tabular}{lcc}
\hline Compound & $\boldsymbol{\Phi}_{\mathrm{fl}}(\mathbf{p H ~ 9 . 0 )} \boldsymbol{a}$ & $\boldsymbol{\Phi}_{\mathrm{fl}}(\mathbf{p H ~ 3 . 4 )} \boldsymbol{b}$ \\
\hline $\mathbf{1}^{\mathrm{Me}}$ & 0.85 & 0.13 \\
$\underline{\mathbf{2}}^{\mathrm{Me}}$ & 0.67 & 0.008 \\
& & 0.005 \\
\hline
\end{tabular}

${ }^{a}$ Data for anionic form were measured in $100 \mathrm{mM}$ sodium phosphate buffer, pH 9.0, containing $0.1 \%$ DMSO as a cosolvent.

${ }^{b}$ Data for neutral form were measured in $100 \mathrm{mM}$ sodium phosphate buffer, $\mathrm{pH} 3.4$, containing $0.1 \%$ DMSO as a cosolvent. For determination of the fluorescence quantum yield, fluorescein in $100 \mathrm{mM}$ aq. $\mathrm{NaOH}(0.85)$ was used as a fluorescence standard. ${ }^{39}$ 